\title{
The Influence of Inbreeding on the Shape and Size of the Skeleton of the European Bison ${ }^{1}$
}

\author{
Franciszek KOBRYNCZUK
}

\begin{abstract}
Kobryniczuk F., 1985: The influence of inbreeding on the shape and size of the skeleton of the European bison. Acta theriol., 30, 25: 379-422 [With 16 Tables \& 10 Figs.]

The influence of inbreeding on the shape and size of the skeleton was examined in 133 European bison. Perkal's method of biological similarity indices, Wroclaw taxonomy and the discrimination function were used for this purpose. It was found that in lowland European bison with less than 10\% admixture of the Caucasian bison blood inbreeding emphasizes the skeletal shapes proper to Caucasian bison. This applies particularly to the skull and thoracic limbs. Inbreeding causes elongation and narrowing of the splanchnocranium in the skul of lowland XCaucasian bison, shortens the scapula of the forelimb and elongates the bone of the tree part limb. It was found that inbreeding has a depressive effect on growth of the skeleton of all inbred European bison, especially females.
\end{abstract}

[Dept. of Animal Anatomy, Warsaw Agric. Univ,, Nowoursynowska 166, 02-776 Warsaw, Poland]

I. Introduction

II. Material and methods

III. Results

Value of coefficients of relationship (R) and inbreeding $(F) \cdot{ }^{*} \cdot{ }^{*}$

1.1. Lowland bison of the Pszczyna line . . . . . . . , $\mathbf{3 8 8}$

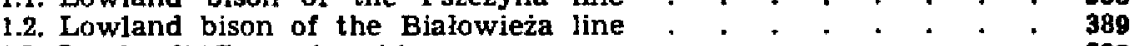

1.3. Lowland $\times$ Caucasian bison . . . . . . . . . . . 390

2. Variations in skeletal dimensions . . . . . . . . . . 390

3. Value of biological similarity indices and their dependence on the

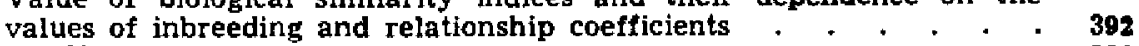

3.1. Skull

3.2. Mandible

3.3. Thoracic bones

3.4. Bones of the limbs

IV. Discussion

3.5. The skeleton as a whole

References

\section{INTRODUCTION}

The restored population of lowland European bison, Bison bonasus (Linnaeus, 1758), which originated from the basic herd of a few animals, was from the start threatened in its existence, not so much by of close inbreeding. It is not therefore surprising that, fearing that the

1 Dedicated to the memory of Professor Kazimierz Krysiak (1907-1977) who taught us that it is due to Poland that the European bison has been saved from extinction. 
restitution of the pure-prea species might end in fiasco, breeding was simultaneously carried out with hybrids of European bison and American bison, domestic cattle and also the Caucasian bison, Bison bonasus caucasicus (Turkin et Satunin, 1904).

The successful development of the world herd of lowland European bison, and also of lowland Caucasian hybrids, however, suggested that a new look should be taken at the problem of inbreeding in these animals. The total number of European bison living in 1978 was 2111, $44^{\%} \%$ of which lived in free-ranging herds (Pucek, 1984).

The observations made up to the present on the European bison's skeleton consisted in classic morphological description of bones and discussion of their growth, development and sex dimorphism (Koch, 1927, 1932; Janicki, 1938; Juskko, 1953; Empel, 1962; Roskosz, 1962; Empel \& Roskosz, 1963). Some papers have also paid attention to differences in the bone structure of the European bison and other related species of the genus Bison and Bos (Allen, 1876; Leitner, 1927; Flerov, 1932; Empel \& Roskosz, 1963; Kobryń, 1973).

Practically no attention has been paid to the effect on the development of the European bison's skeleton of habitat and genetic factors. The lack of interest in this subject was due to objective causes, the most important of which was the lack of sufficiently abundant material permitting of carrying out the appropriate mathematical and statistical studies. The opportunity for such studies came closer with increase in the number of skeletons of animals differing as to their degree of inbreeding.

This study is aimed chiefly at demonstrating the depressive effect of inbreeding on postnatal growth of the European bison's skeleton. It is also intended to supply information on variations in shape of animals' bones resulting from inbreeding. The purpose of the studies is also to show that such changes in Lowland $\times$ Caucasian bison constitute a reconstruction of the skeletal shapes of their forbears - Caucasian bison.

Duerst's osteometry (1926), Perkal's statistical method of biological similarity indices (1953a), Fisher's discrimination (1936) and Wroclaw taxonomy (Florek et al., 1951), were all used for these studies, which may prove of use in further breeding of the European bison, particularly the Lowland $\times$ Caucasian herd.

\section{MATERIAL AND METHODS}

The study material consisted of the bones of 133 European bison from zoological gardens, reserves and free-ranging breeding centres, and forms part of 
Table 1

List of the European bisons studied.

Consecutive number, pedigree number and the name of the individual are given. $\mathrm{M}$ - male, $\mathrm{F}$ - female.

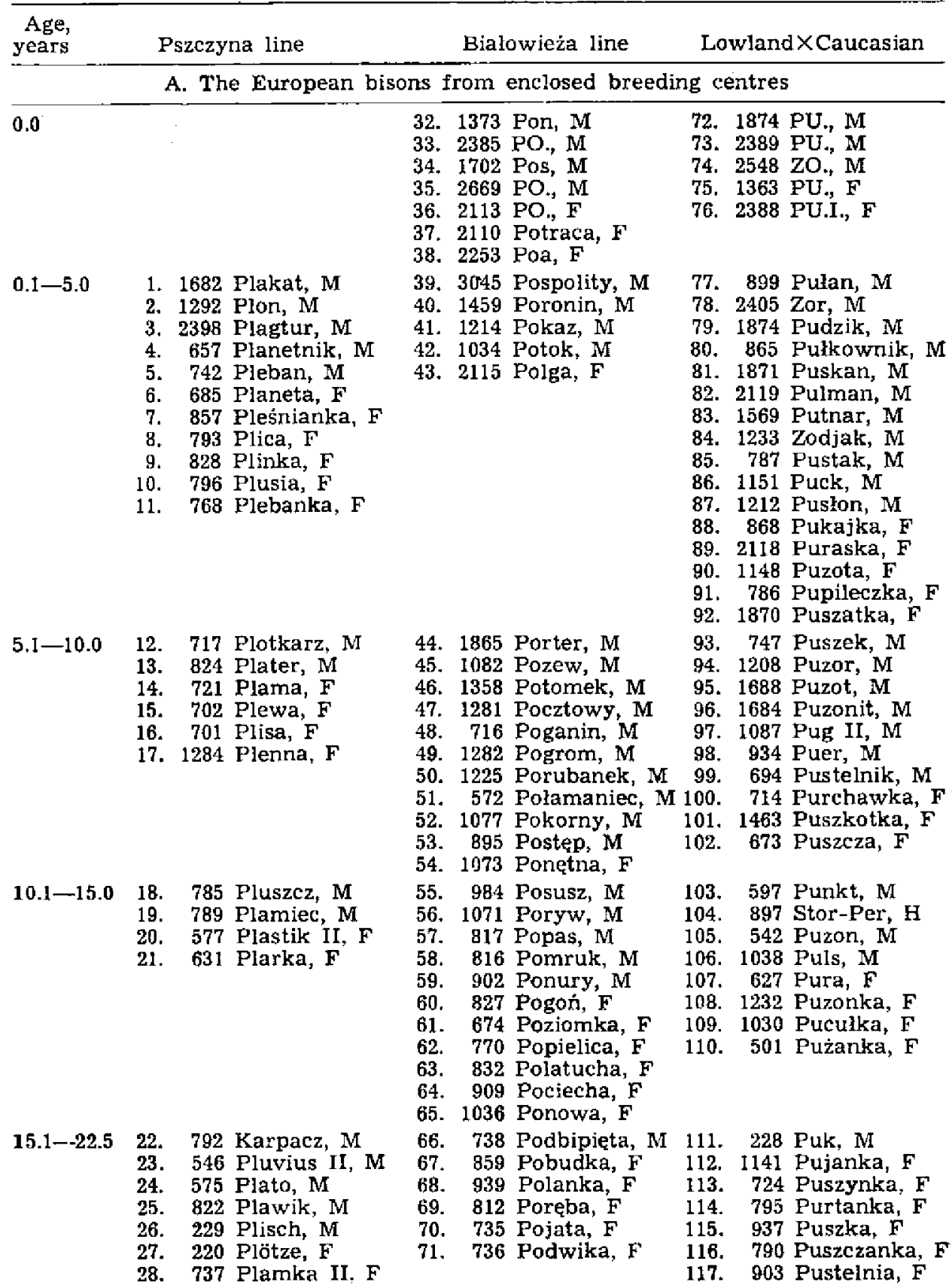




\begin{tabular}{|c|c|c|c|c|c|c|c|}
\hline Total & $\begin{array}{l}29 . \\
30 . \\
31 .\end{array}$ & $\begin{array}{l}256 \text { Pleinze, } F \\
219 \text { Planarie, } F \\
255 \text { Pliete } \\
31(14 \mathrm{M}, 17 \mathrm{~F})\end{array}$ & & $40(24 \mathrm{M}$ & F) & $46(26 \mathrm{M}, 20$ & F) \\
\hline \multicolumn{8}{|c|}{ B. Free-ranging European bison } \\
\hline & & \multicolumn{3}{|c|}{ Lowland No. 118-133 } & \multicolumn{3}{|c|}{ Caucasian No. 134-155 } \\
\hline $\begin{array}{l}\text { Young } \\
\text { Adult } \\
\text { Total }\end{array}$ & & $\begin{array}{r}9 \\
5 \\
14\end{array}$ & $\frac{2}{2}$ & $\begin{array}{r}11 \\
5 \\
16\end{array}$ & $\begin{array}{r}2 \\
10 \\
12\end{array}$ & $\begin{array}{r}2 \\
8 \\
10\end{array}$ & $\begin{array}{r}4 \\
18 \\
22\end{array}$ \\
\hline
\end{tabular}

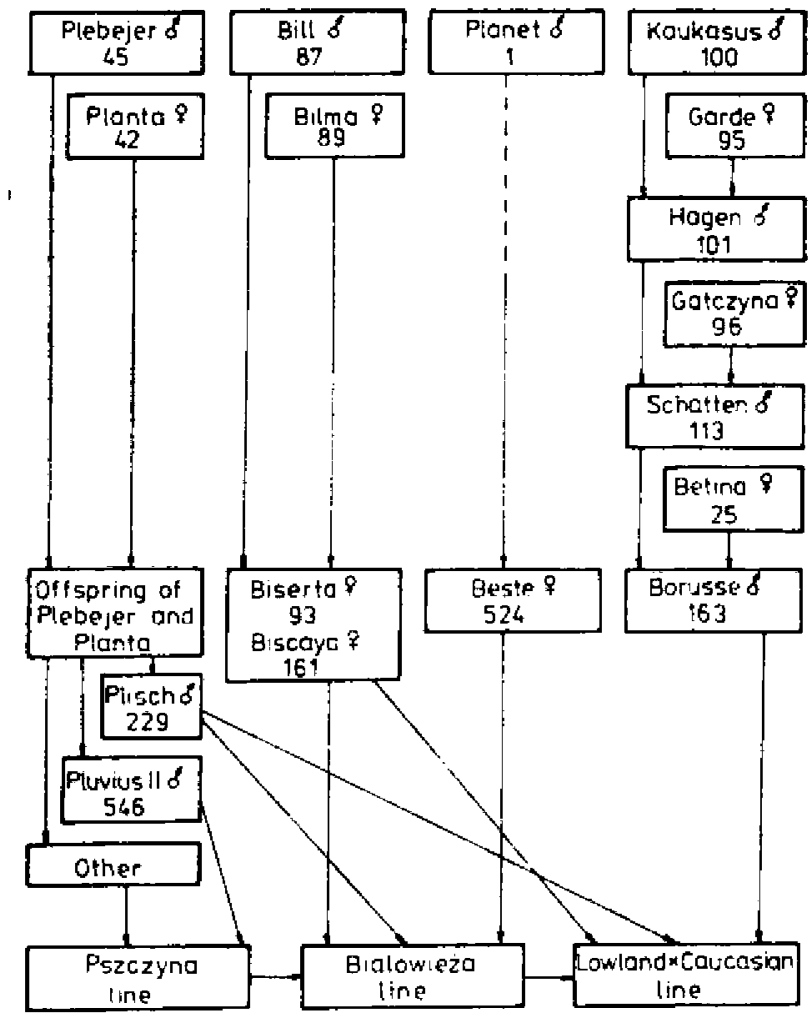

Fig. I. Diagram of formation of three breeding lines of the European bison (Numbers indicate pedigree numbers).

the museum collection of the Department of Animal Anatomy, Veterinary Faculty, Warsaw.

The material was divided into three groups (Table 1), the first of which included lowland bison of the Pszczyna line (LP), the second - lowland bison of the Bialowieza line (LB) and the third - lowlandXCatucasian bison (LC). A fourth, additional group consisted of European bison of unknown pedigree from free-ranging centres. 
For the purpose of comparison 22 skulls of pure-bred Caucasian bison (C), kept in the Zoological Institute, USSR Academy of Sciences in Leningrad, were added to the study material (Table 1 ).

The age of animals originating from enclosed breeding centres was established by means of the European Bison Pedigree Books (Zabiński, 1947-65, Zabinski \& Raczynski, 1972), while the age of European bison born free, this including Caucasian bison, was given approximately (young, adult) on the basis of the state of epjphysial ossification of sutures and cartilages, using Koch's (1927, 1932) and Empel's (1962) identifications.

For all European bison of known pedigree estimates were made of coefficients of inbreeding $(F)$ and of relationship $(R)$ up to three forbears from which the three breeding lines start: lowland of the Pszczyna Iine, lowland of the Bialowieża line and lowland $\times$ Caucasian (Fig. 1).

\section{Table 2}

Approximate values of inbreeding coefficients $(F)$. Given names of bison replaced by numbers as in Table 1. Numbers above and below the line are related to males and females, respectively.

\begin{tabular}{|c|c|c|c|}
\hline$F$ & Pszczyma line & Białowieża line & Lowland $\times$ Caucasian \\
\hline 0.00 & & $\frac{51}{62 \quad 6469}$ & $\frac{103}{100} \frac{105111}{110}$ \\
\hline $0.01-0.10$ & & & $\frac{8499}{90}$ \\
\hline \multirow[t]{2}{*}{$0.11-0.20$} & & $32 \quad 33$ & $\begin{array}{llllll}72 & 77 & 79 & 80 & 81 & 85 \\
87 & 93\end{array}$ \\
\hline & & & 112116 \\
\hline \multirow[t]{2}{*}{$0.21-0.30$} & $\frac{26}{213031}$ & $\begin{array}{llllll}34 & 35 & 39 & 41 & 45 & 47 \\
49 & 53 & 55 & 56 & 59 & \end{array}$ & $\begin{array}{lllll}74 & 83 & 98 & 104 & 106 \\
88 & 91 & 102 & 107 & 108 \\
\end{array}$ \\
\hline & & $\begin{array}{llllll}36 & 37 & 38 & 43 & 54 & 63\end{array}$ & $109 \quad 113 \quad 114 \quad 117$ \\
\hline \multirow[t]{2}{*}{$0.31-0.40$} & $\begin{array}{llll}18 & 22 & 23 & 24 \\
25 & & & \end{array}$ & $\begin{array}{llllll}40 & 44 & 46 & 50 & 48 & 52 \\
58\end{array}$ & $\begin{array}{llllll}78 & 82 & 86 & 94 & 96 & 97 \\
75 & 89 & 92 & 101 & 115\end{array}$ \\
\hline & $\begin{array}{l}6814 \quad 15 \quad 20 \\
2729\end{array}$ & 61657071 & \\
\hline $0.41-0.50$ & $\begin{array}{rrrrr}1 & 4 & 5 & 12 & 19 \\
7 & 10 & 11 & 16 \\
17 & 28 & & \end{array}$ & $\begin{array}{lll}42 & 57 & 66 \\
60 & 67 & 68\end{array}$ & 76 \\
\hline $0.51-0.60$ & $\frac{2313}{9}$ & & 73 \\
\hline
\end{tabular}

Wright's (1921) equation was used for determining coefficients of inbreeding:

$$
F_{x}=\sum\left[\left(\frac{1}{2}\right)^{n_{1}+n_{2}+1}\left(1+F_{0}\right)\right],
$$

where $F_{x}$ and $F_{0}$ are the inbreeding coefficients of an individual and common forbear, $n_{1}, n_{2}$ number of generations from the common forbear to the father of the individual and mother.

Inbreeding coefficients of the different individuals were kept in working tables, 
while the bison were classified according to the approximate value of these coefficients (Table 2).

An estimate was also made for lowland $\times$ Caucasian bison having the genes of three forbears, i.e. Plebejer (pedigree no. 45), Bill (87) and Kaukasus (100), of the partial inbreeding coefficients $\left(F_{P[}, F_{B i}\right.$ and $\left.F_{K}\right)$, taking into consideration the common forbears of the given line. The most important among them proved to be the partial coefficient $F_{K}$ calculated on the basis of the presence in the pedigrees of only those forbears having Kaukasus genes. The approximate values of this coefficient have therefore been given in Table 3.

Table 3

Approximate values of inbreeding coefficients $\left(F_{K}\right)$ for lowland $\times$ Caucasian bison. Given names of bison replaced by numbers as in Table 1.

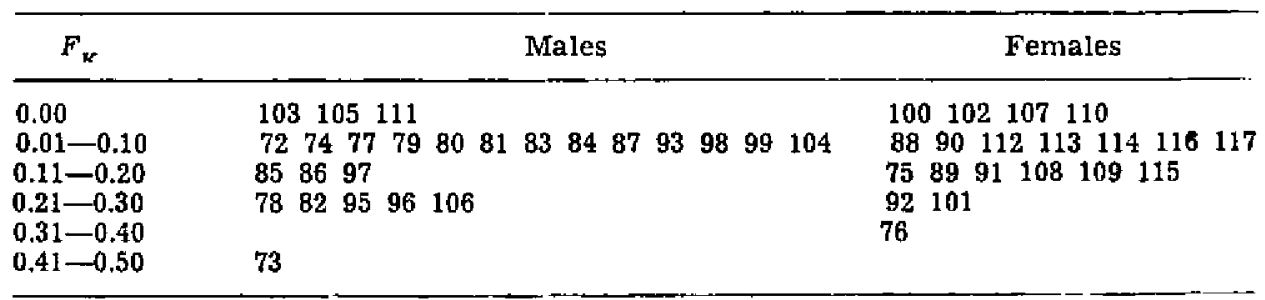
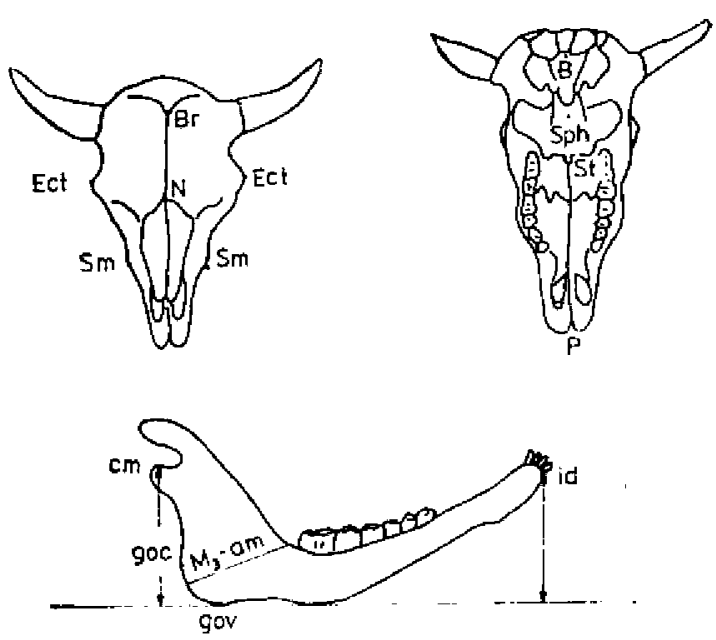

Fig. 2. Measurement sites on skull and mandible. See text for the definitions.

Relationship coefficients in a straight line to the above forbears - founders of the breeding lines - were estimated, using the equation:

$$
R_{\mathrm{od}}=\sum\left(\frac{1}{2}\right)^{n} \sqrt{\frac{1+F_{\mathrm{a}}}{1+F_{\mathrm{o}}}}
$$

where $R_{o a}$ is the relationship coefficient between the forbear and progeny, $F_{a}$ and $F_{o}-$ inbreeding coefficient of forbear and progeny, $n$ - number of sections of the path. 
When determining coefficients $F$ and $R$, forbears originating from Planet (pedigree no. 1) were not taken into consideration since the female Beste (524), as its only progeny, was included in the herd for reproduction later, and contributed a low percentage of individuals to the population (Fig. 1).

The second stage of the studies, after estimating inbreeding and relationship to forbears coefficients, was to carry out measurements of selected elements of the skeleton and to convert them into Perkal's (1953a, 1958) natural similarity indices.
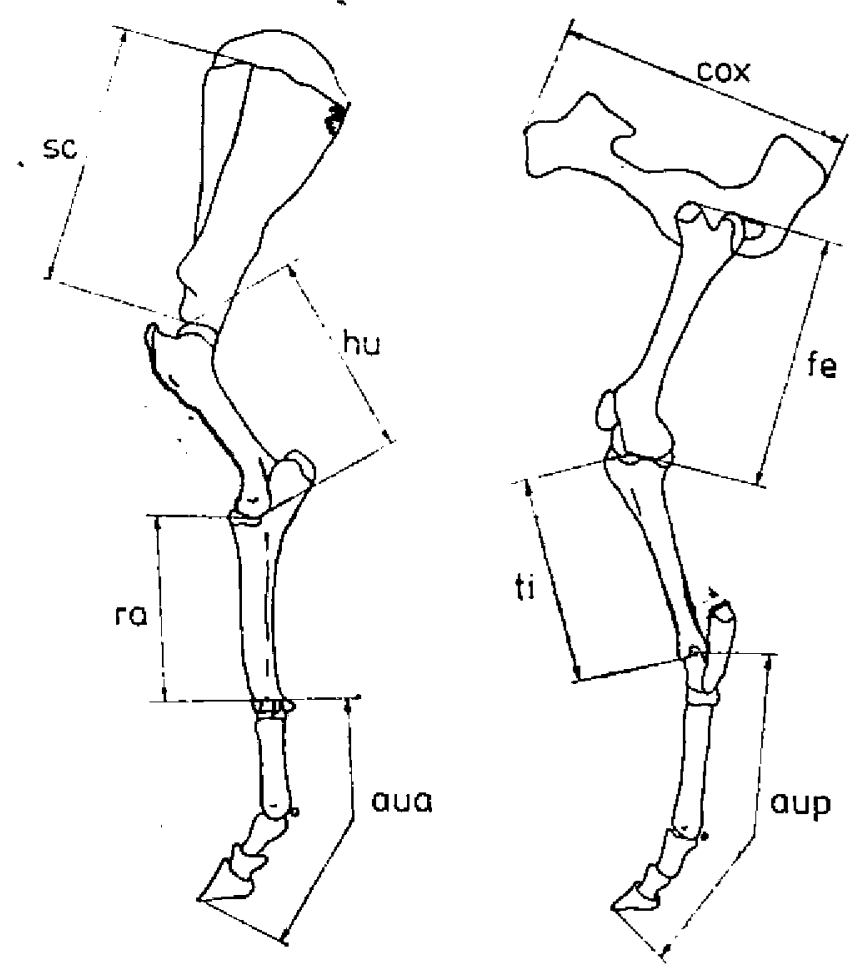

Fig. 3. Measurement sites on limb bones. See text for definitions.

Duerst's (1926) osteometry was employed in measurements and use was also made of indices of a technical nature given in the papers by Empel (1962), Roskosz (1962), Empel \& Roskosz (1963) and Kobryń (1973). Measurement sites on the skull, mandible and limb bones are shown in Figures 2 and 3 . Their symbols have been taken either from anthropology or formed from the first letters of the Latin terms, and these have been used in the tables and figures instead of the name of the measurement, and have also been used to indicate variables. Definition of measurements is given below.

Skull

1. Basal length of skull - Basion - Prosthion (BP)

2. Length of base of splanchnocranium - Staphylion-Prosthion (StP)

3. Length of base of neurocranium - Basion-Staphylion (BSt)

4. Interorbital breadth - Ectoorbitale-Ectoorbitale (EctEct) 
5. Breadth of splanchnocranium - Supramolare-Supramolare (SmSm):

6. Heigh* of splanchnocranium - Staphylion-Nasion (StN)

7. Heif,ht of neurocranium - Sphenobasion-Bregma ( $\mathrm{SphBr}$ )

Mandible

8. Length of mandible - Infradentale-Gonion caudale (idgoc)

y. Maximum length of mandible - Infradentale-Coronion mediale (idcm)

10. Height of mandible (in projection) - Infradentale-Gonion ventrale (idgov)

11. Height of mandible to Coronion mediale (in projection) - Gonion ventrale-Coronion mediale (govem)

12. Linear breadth of ramus - maximum breadth from site on $M_{3}$ to the mandibular angle $-\mathrm{M}_{3}-$ angulus mandibulae $\left(\mathrm{M}_{3}\right.$-am)

\section{Thoracic bones}

13. Arcuate length of rib I - os costale I (coI)

14. Arcuate length of rib V - os costale $\mathrm{V}$ (coV)

15. Arcuate length of $\mathrm{rib}$ IX - os costale IX (coIX)

16. Arcuate length of rib XIII - os costale XIII (coXIII)

17. Length of sternum - sternum (ster)

\section{Limb bones}

18. Length of scapula - scapula (sc) measured along crest

19. Length of humerus - humerus (hu) measured from the most proximal site of head to the most distal site on condyle

20. Maximum length of radius - radius (ra)

21. Length of autopodium of fore-limb - autopodium anterius (aua) as sum total of height of carpus, length of metacarpus (Mc) and length of phalanges

22. Maximum length of hipbone - os coxae (cox) measured from the most proximal site on tuber coxae to the most distal site on the tuber ischii

23. Length of femoral bone - femur (fe) measured from the most proximal site on the capitulum to the most distal site on the medial condyle

24. Maximum length of tibia - tibia (ti)

25. Length of autopodium of hind limb - autopodium posterius (aup) as sum total of tarsus height, length of metatarsus (Mt) and length of phalanges

Skeleton as a whole

26. Basal length of skull (BP) as for 1.

27. Length of spinal column - columna vertebralis (col) - measurements after Roskosz (1962)

28. Length of forelimb - membrum thoracicum (meth) as sum total of length of bones as given in $18-21$

29. Length of hind limb - membrum pelvinum (mep) as sum total of length of bones as given in $22-25$

Mean values $(\mathrm{mm})$ for the above parameters $(\bar{x})$ for the sample including lowland and lowland XCaucasian bison, and separately for Caucasian bison are given in Table 4. Treating the material as a whole necessitated the use of this method.

Individual measurements of different parts of the skeleton have been converted to normalized characters (C), which were next converted to Perkal's biological similarity indices (P) (1953a). 
The equation for the normalized character takes the following form:

$$
C_{v 1}=\frac{x_{t f}-\bar{x}}{S D}
$$

If for the sake of example we convert the value of the parameter Basion-Prosthion (BP) in the bison Pokaz, i.e. $467 \mathrm{~mm}$, into a normalized character, with $\bar{x}-455.5 \mathrm{~mm}$ and SD -39.1 (data from Table 4) we obtain: $C_{t j}=+0.294$. The following normalized characters were obtained for all seven parameters of Pokaz's skull:

$\begin{array}{ccccccc}\text { BP } & \text { StP } & \text { Bst } & \text { EctEct } & \text { SmSm } & \text { StN } & \text { SphBr } \\ +0.294 & -0.321 & +0.925 & +0.792 & +0.011 & +0.675 & +1.499\end{array}$

The mean value for all the normalized characters in this example is +0.553 , In statistical terminology this is termed normalized magnitude $-M$ or index of normalized magnitude (Perkal, 1953a; Schmidt, 1964). This index is a relative number - taking on positive values for large objects and negative for small.

In the present studies a unit was introduced for adult (over $4-5$ years) but not yet old (below 14-16 years) European bison which is the quotient of normalized magnitude $(M)$ and age in years (a), giving it the symbol $V$ (for the skull $V_{c r^{\prime}}$ thorax $-V_{\text {th }}$, limbs $-V_{\text {me }}$ and whole skeleton $-V_{\text {sce }}$ ). In view of the fact that both heights of the mandible (idgov and govem) were measured in projection, normalized magnitude $(M)$ was not determined for this bone.

The index of biological similarity $(P)$ is obtained by subtracting normalized magnitude $(M)$ from the normalized character (C) according to the equation;

$$
P_{i j}=C_{i j}-M
$$

Conversion of the normalized character relating to Basion-Prosthion for Pokaz $\left(C_{\mathrm{BP}}\right)$ to index of biological similarity gives: $P_{\mathrm{BP}}=-0.259$.

The author of this method recommends multiplying the original indices of similarity by the multiple 10 in order to obtain whole numbers. In the present paper these indices have been multiplied by 100 , for instance for all parameters of Pokaz's skull, after rounding them up they have the following value:

$$
\begin{array}{lcccccc}
\text { BP } & \text { StP } & \text { BSt } & \text { EctEct } & \text { SmSm } & \text { StN } & \text { SphBr } \\
-26 & -87 & +37 & +24 & -54 & +12 & +94
\end{array}
$$

It must be remembered that the sum total of these indices is 0 .

Their interpretation is as follows: the norm for lowland and lowland $\times$ Caucasian bison is an individual possessing each of the seven skull indices equal to 0 . The sense of Perkal's method is to normalize parameters to 0 . Certain skulls may be close to this or similar to a greater or lesser degree. For instance Pokaz's skull in relation to this norm has in the first place relatively too great a height of the neurocranium ( $\mathrm{SphBr}$ ) and too short a base of the splanchnocranium (StP). The remaining indices also differ from 0 .

Indices of biological similarity $(P)$, termed indices in the further part of this paper for the sake of brevity, have been treated as dependent variables $(y)$ and coefficients of inbreeding $(F)$, of relationship $(R)$ and age $(a)-$ as independent variables $(x)$. All significant correlations $(p \leqslant 0.01, p \leqslant 0.05)$ between these variables $\left(r_{y x}\right)$, and also the 1 st degree regression equation, are the basic results of this study, since they provide mathematical proof that inbreding influences the shape of the bison skeleton (Table 5). 
Tables 6, 7, 9-12 give values only of those indices which enter into significant correlation with the above-mentioned independent variables. The values of the remaining indices, which inbreeding does not alter, have been kept in the working tables.

Taking the mean values of indices for each group of animals as a basis, similarity heptagons were constructed to illustrate the shapes of skulls in different breeding lines, separately for males and females (Fig. 6). The figure lying centrally represents the skull of an individual for which each of seven indices is 0 . It was assumed that zero level is a circle and therefore all apexes of the heptagon of the skull of this individual come within this circle. A changes in the mean value of the similarity index in the given line shifts its relevant apex to the outside, since its value either increases to the interior, or this value becomes less than zero, in both cases with appropriately proportionate distance.

In order to determine the recurrence of craniological characters acquired as the effect of inbreeding, taxonomy and discrimination of the skeletons were ccarried out using the Wroclaw taxonomy, that is, genealogical dendrite taxonomy (Florek et al., 1951; Perkal, 1953b) and also Fisher's method (1936), arranging in line different elements of the skeleton. The genealogical dendrite method was used for skulls only (Fig. 7 and 8), while Fisher's discrimination was extended to other bones also.

The distances between points on the dendrite are the least differences between skulI indices. For instance Pokaz's skull, numbered 41 (Table 1, Fig. 7) is most similar to the skull of Pustak (no. 85), because the distance dividing the two skulls in the dendrite is the least distance for Pokaz. This distance was obtained as follows:

Skull indices of Pokaz
Differences

$\begin{array}{rrrrrrr}-26 & -87 & +37 & +24 & -54 & +12 & +94 \\ +3 & -25 & +33 & -1 & -64 & -8 & +62 \\ 29 & 62 & 4 & 25 & 10 & 20 & 32\end{array}$

The sum total of differences in the example given is 182. This is a considerable distance, allocating Pokaz's skull to the periphery of the dendrite. It follows that in respect of shape it is far from the norm, to which skulls lying in the middle of the dendrite are close.

The group dendrite (Fig. B) was constructed in a similar way on the basis of mean indices for the various breeding lines.

Anatomical terminology was taken from Veterinary Anatomical Nomenclature (1978), but the former meaning of the term "skull-cranium", applying to splanchnocranium and neurocranium, as used in Empel's paper (1962) has been re"tained.

\section{RESULTS}

\section{Value of Coefficients of Relationship (R) and Inbreeding (F)}

\subsection{Lowland Bison of the Pszczyna Line}

The bison of this line originate from the breeding reserve started in 1865 in Silesia. These animals developed from a herd of three cows and one bull purchased at Bialowieża. From 1880--1909 it was further 
enriched with new bison, as during this period five cows were introduced from Białowieża and three bulls - two from Berlin and one from Dresden (Czudek, 1930). During the First World War this herd was almost completely liquidated, only a pair of bison - Plebejer (pedigree no. 45) and Planta (42) surviving to initiate the current line of Pszczyna bison (Table 1, Fig. 1).

The relationship of the progeny of this line to Plebejer $\left(R_{P l}\right)$ is closer than to Planta, since during the first period of restitution Plebejer mated with its own daughters, whereas Planta had no calves with the male line of its progeny. In the majority of cases the value of relationship to Plebejer is close to $55 \%$, sporadically being greater, and in the case of the female no. 27 (Table 1), as much as $70 \%$.

The result of inbreeding within the Pszczyna herd consists in fairly high inbreeding coefficients $(F)$, exceeding in the case of some individuals a value of 0.5 (Table 2). No animals are encountered in this group of bison free from inbreeding and the lowest inbreeding coefficient is 0.25 .

\subsection{Lowland Bison of the Białowieża Line}

The forbears of today's Bialowieża European bison are two bulls: the above-mentioned Plebejer and Bill (pedigree no. 87), whose parents lived in the free-ranging Bialowieża herd before it was completely destroyed during World War I.

Bill mated with the Bialowieża cow Bilma (pedigree no. 89) and had two daughters (Fig. 1): Biserta (93) and Biscaya (161). They were mated with the Pszczyna line Plisch (229), a grandson of Plebejer. As there was no reproducer available deriving directly from the free-ranging Bialowieża bison, the percentage of Plebejer's blood increased in the subsequent generations also because Plisch mated with its own daughters. For this reason the relationship of contemporary Bialowieza bison to Plebejer $\left(R_{P t}\right)$ is greater than to Bill $\left(R_{B i}\right)$. The relationship coefficient in the first case comes within limits of 18.0 to $48.0 \%$, and in the second only from 3.0 to $12.5 \%$.

Some of the Bialowieża bison (nos. 62,69-Table 1) do not descend in a direct line from Biserta or Biscaya, but from Besta (pedigree no. 524) - the third, previously-mentioned original mother of this line, and hence they exhibit no relationship to Bill (Fig. 1).

The inbreeding coefficients in the Białowieża herd do not exceed the value of 0.5, as occurred in the case of the Pszczyna line bison (Table 2). In six animals they vary from 0.4 to 0.5 , but apart from four non25 - Acta Therlologtca 
inbred animals (nos. 51,62, 64,69- Table 1), the remainder of the animals have values from 0.2 to 0.4 .

\subsection{Lowland $\times$ Caucasian Bison}

Before Plisch became a mature reproducer, the Białowieża cows Biserta and Biscaya had been covered several times by the bull Borusse (pedigree no. 163 ) - a lowland $\times$ Caucasian hybrid with $12.5 \%$ Caucasian bison blood. The Bialowieża $\times$ Caucasian females born from these matings had therefore only $6.25 \%$ of this blood. It was impossible to inclease the Ievel of the Caucasian bison genes as there were no suitable males in its population. The next reproducer of this line, after Borusse, was Plisch (no. $26-$ Table 1), giving progeny with an even smaller proportion of Kaukasus's (pedigree no. 100) genes.

In view of the foregoing the predominant number of animals in the sample exhibit relationship to three forbears: Plebejer $(12.4-35.6 \%$, Bill $(7.8-25.0 \%)$ and Kaukasus - a representative of Caucasian bison $(1.6-6.2 \%)$. As in occasional cases Borusse's daughters were covered by their brother Puk (pedigree no. 228), and not by Plisch, the resulting bison (nos. 85, 91, 104, 110 - Table 1) reveal no relationship to Plebejer.

The most inbred of the lowland $\times$ Caucasian animals are two newborn bison (nos. 73,76 ) and there are also five bison not originating from inbreeding (nos. 100,103,105, 110, 111). The inbreeding coefficients for the remaining animals come within limits of 0.1 to 0.4 . Partial coefficients $F_{K}$, estimated on the basis of the presence in pedigrees only of forbears having Kaukasus's genes, are on an average less than $F$ in the group of bison analyzed (Table 3 ).

\section{Variations in Skeletal Dimensions}

The greatest variation among the seven skull parameters is exhibited by interorbital breadth (EctEct), and the least - length of base of splanchnocranium (StP). The two mandibular lengths (idcm, idgoc) are also less variable than the remaining dimensions of this bone (Table 4). The skull parameters of Caucasian bison are characterized by lesser variability than those of lowland and lowland $\times$ Caucasian bison treated jointly (Table 4 ).

Variation is considerable in thoracic elements (CV $-23 \%$ ), the only exception to this being costal bone $\mathrm{V}(\mathrm{CV}-8.5$, Table 4).

The four parts of the limbs: zonopodium, stylopodium, zeugopodium and autopodium - are characterized by the following regularity: the more peripherally situated the given part, the lesser the variations in 
its length (Table 4). This applies particularly to the thoracic limb. It was also found that variation in the above parts is greater in the foreleg than in the hind limb.

Table 4

Mean values ( $\bar{x} \pm S D$ ) and coefficients of variation (CV) for bone measurements (mm).

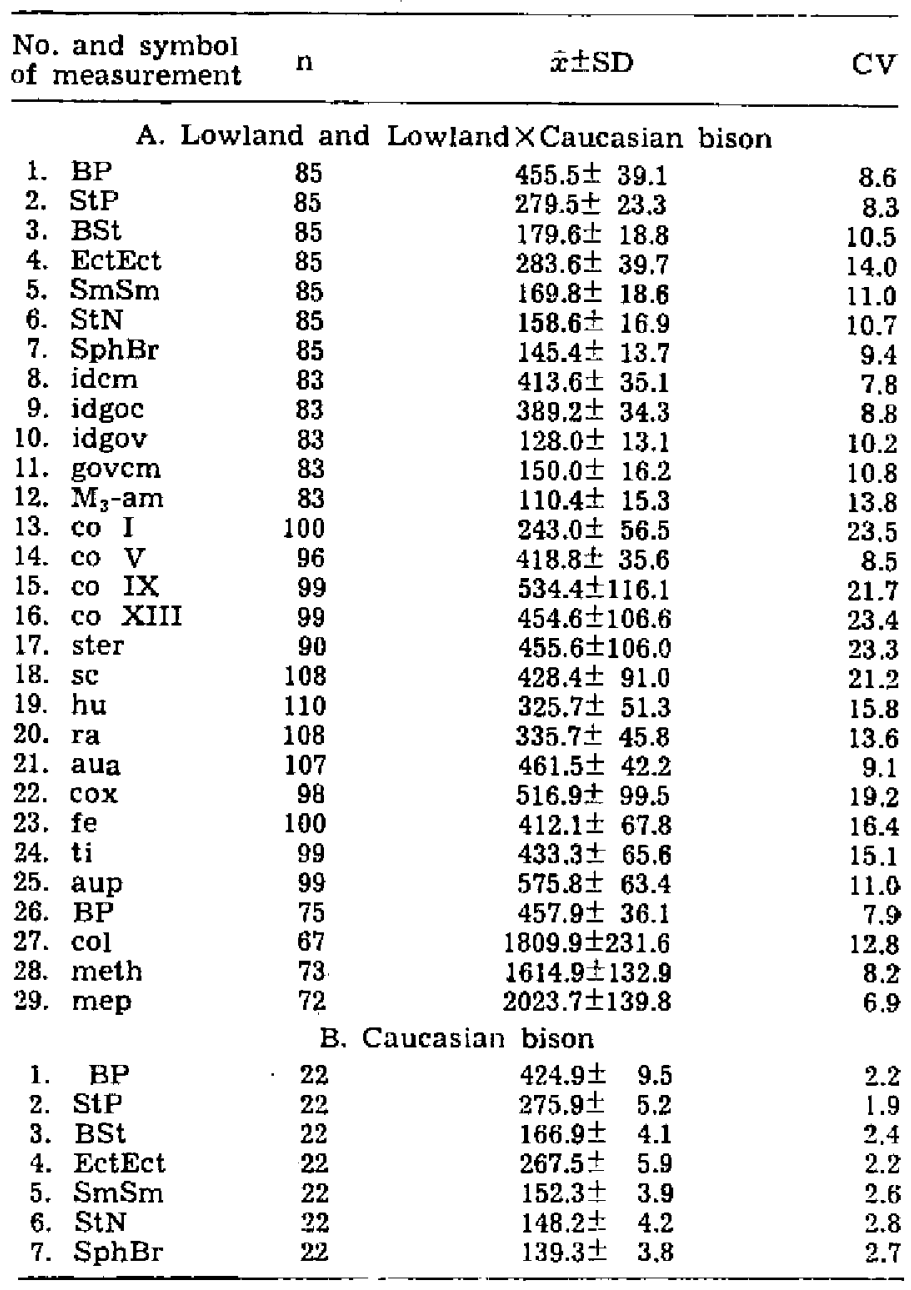

In the skeleton as a whole, represented by the axial skeleton and members, the considerable variation in length of vertebral column and lesser variation in length of the base of the skull and the pelvic limb are remarkable (Table 4). 
3. Value of Biological Similarity Indices and ita Dependence on the Values of Inbreeding and Relationship Coefficients

3.1. Skull

The value of biological similarity indices comes within limits of -100 to +100 , and on an average exhibits the least fluctuations round zaro in Pszczyna line bison and greatest in the lowland $\times$ Caucasian line. Not a single individual was encountered, the skull of which had all indices of 0 , which would correspond to model proportions.

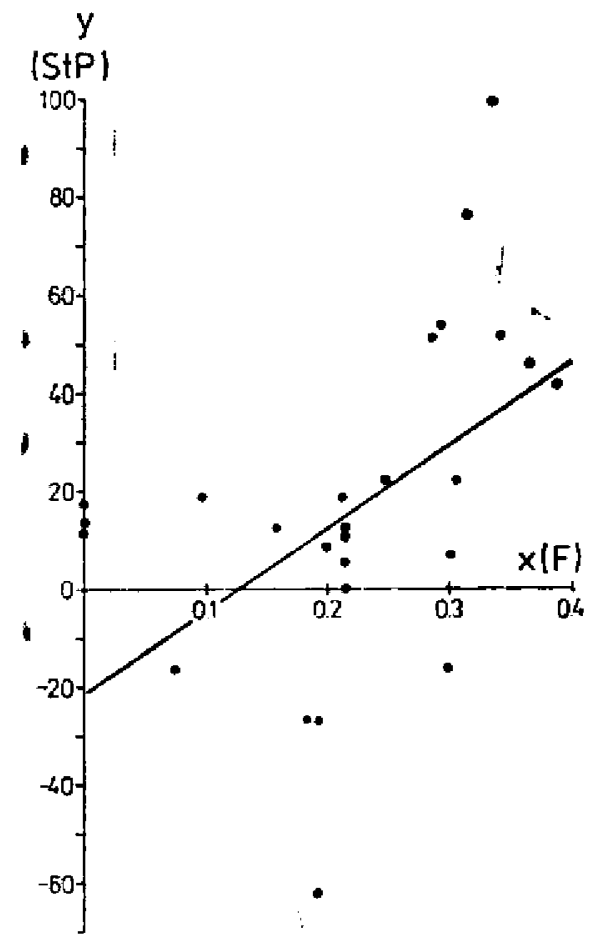

Fig. 4. Relation botween index of length of splanchnocranium (StP) and inbreeding coefficient $(F)$ in Lowland $\times$ Caucasian bison.

Detailed mathematical and statistical studies showed that the value of skull indices in Pszczyna and Bialowieża line lowland bison does not vary when the degree of inbreeding intensifies within the given line. On the other hand some biological similarity indices of the skull in lowland $\times$ Caucasian bison depend on the degree of inbreeding expressed by the coefficients $F$ and $F_{K}$. Thus in these bison of both sexes the index for length of the base of the neurocranium (BSt) decreases when the inbreeding coefficient $(F)$ increases, as shown by the regression equation and highly significant coefficient of linear correlation (Table 5 - equation 1, Table 6). In the same bison the consequence of intensification of inbreeding is the compensatory elongation of the 
base of the splanchocranium - StPi (Table 5 - eq. 2, Table 6, Fig. 4).

More significant relations are observed in these bison when skull indices are confronted with the value of the partial coefficient of inbreeding $F_{\boldsymbol{K}}$. For instance increase in inbreeding expressed in this way leads to shortening of the base of the neurocranium - BSt (Table 5 - equation 3, Table 7) and elongation of the base of the splanchnocranium - StP (Table 5 - equation 4, Table 7) which corresponds to the

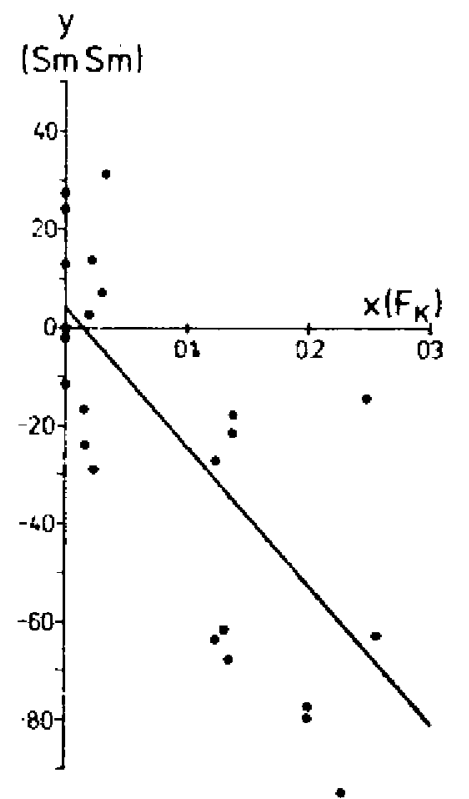

Fig. 5. Relation between index of breadth of splanchnocranium ( $\mathrm{SmSm}$ ) and inbreeding coefficient $\left(\boldsymbol{F}_{\boldsymbol{K}}\right)$ in Lowland $\times$ Caucasian bisons.

processes expressed by equations 1 and 2. As the result of these changes in the shape of the skull in inbred lowlandXCaucasian bison site Staphylion (St - Fig. 2) situated on the margin of palatum osseum, is shifted to the rear, changing the relation of basal length of both parts of the skull. At the same time there is a shift in these animals of site Prosthion in a forwards direction (Fig. 2), indicating the oral extension of palatum osseum, which results in elongation of the whole base of the skull - BP (Table 5 - equation 5, Table 7).

This does not take place without affecting the dimension of skull breadth. Thus the consequence of these changes in shape is significant narrowing of the splanchnocranium ( $\mathrm{SmSm}$ ), of course progressing with increased intensity of inbreeding (Table 5 - equation 6 , Table 7, Fig. 5).

The mean values of skull indices for inbred lowland $\times$ Caucasian bison differ from their counterparts for lowland bison, but are close to the mean skull indices for pure-bred Caucasian bison (Table 8). 
Table 5

List of regression equations and correlation coefficients $(r)$ between biological similarity indices and their derivatives

(y) and coefficients of inbreeding and relationship ( $x$ ).

\begin{tabular}{|c|c|c|c|c|}
\hline \multirow{2}{*}{ No. } & \multirow{2}{*}{ Equation } & \multirow{2}{*}{$r_{y x}$} & \multicolumn{2}{|c|}{ Symbol of variables } \\
\hline & & & $y$ & $x$ \\
\hline 1. & $y=-124.00 x+22.82$ & $-0.518^{2}$ & BSt & $F$ \\
\hline 2. & $y=+169.22 x-20.89$ & +0.544. & StP & $F$ \\
\hline 3. & $y=-148.19 x+9.58$ & $-0.466^{1}$ & BSt & $F_{K}$ \\
\hline 4. & $y=+216.35 x+4.11$ & $+0.528^{2}$ & StP & $F_{K}$ \\
\hline 5. & $y=+71.40 x+5.57$ & $+0.406^{1}$ & $\mathrm{BP}$ & $F_{K}^{K}$ \\
\hline 6. & $y=-287.65 x+5.42$ & $-0.670^{2}$ & $\mathrm{SmSm}$ & $F_{K}^{K}$ \\
\hline 7. & $y=-2.78 x+0.48$ & $-0.535^{2}$ & $\mathrm{z}$ & $F$ \\
\hline 8. & $y=-22.14 x+17.47$ & -0.4991 & $\mathrm{~V}_{\mathrm{cr}}$ & $F$ \\
\hline 9. & $y=-22.86 x+4.55$ & $-0.581^{2}$ & $\mathrm{~V}_{\mathrm{Cr}}$ & $F$ \\
\hline 10. & $y=-295.36 x+117.30$ & $-0.616^{2}$ & $\mathrm{M}_{3}-\mathrm{am}$ & $F$ \\
\hline 11. & $y=+275.75 x-89.71$ & $\div 0.566^{8}$ & $\mathrm{M}_{3}$-am & $F$ \\
\hline 12. & $y=-0.20 x+0.08$ & -0.4071 & $\mathrm{~V}_{\mathrm{th}}$ & $F$ \\
\hline 13. & $y=+-75.75 x-25.32$ & $+0.622^{1}$ & $\mathrm{fe}$ & $F$ \\
\hline 14. & $y=+32.45 x-6.63$ & +0.377 & fe & $F$ \\
\hline 15. & $y=+56.51 x-3.43$ & +0.365 & hu & $F_{K}$ \\
\hline 16. & $y=+66.88 x-0.03$ & $+0.405^{1}$ & ra & $F_{\mathrm{K}}$ \\
\hline 17. & $y=+122.64 x-13.81$ & +0.4061 & fe & $F_{\mathrm{Pl}}$ \\
\hline 18. & $y=-1.22 x+25.94$ & -0.3341 & aua & $R_{P l}$ \\
\hline 19. & $y=+9.81 x-25.70$ & +0.4251 & aua & $R_{K}$ \\
\hline 20. & $y=-0.36 x+0.06$ & $-0.528^{1}$ & $V_{\text {sce }}$ & \\
\hline
\end{tabular}

$10.01<p \leqslant 0.05,20.001<p \leqslant 0.01$.

\section{Table 6}

Mean values for selected biological similarity indices for skulls and mandibles of Lowland XCaucasian bison in classes defined by value of inbreeding coefficient $(F)$.

\begin{tabular}{crrrr}
\hline$F$ & BSt & StP & govem & $\mathrm{M}_{3}$-am \\
\hline 0.00 & +10.2 & +5.0 & -43.0 & +32.3 \\
$0.01-0.10$ & +36.5 & +1.5 & +67.0 & -23.5 \\
$0.11-0.20$ & +9.0 & +18.4 & +116.4 & -24.2 \\
$0.21-0.30$ & -8.0 & +12.2 & -0.7 & +8.0 \\
$0.31-0.40$ & -17.8 & +41.9 & +89.7 & -4.0 \\
\hline
\end{tabular}

Table 7

Mean values for selected biological similarity indices for the skeleton of Lowland $\times$ Caucasian bison in classes defined by value of partial inbreeding coefficient $\left(F_{\mathbf{K}}\right)$.

\begin{tabular}{ccccccccccc}
\hline$F_{K}$ & BP & StP & BSt & SmSm & govcm & $\mathrm{M}_{\mathbf{3}}$-am & coIX & ster & hu & ra \\
\hline 0.00 & +10.7 & +1.8 & +6.5 & +8.5 & -14.0 & +16.6 & +1.0 & +2.0 & +1.7 & -0.3 \\
$0.01-0.10$ & +5.3 & -5.1 & +10.2 & +6.7 & +60.3 & -12.4 & +4.8 & +3.8 & +5.8 & -9.7 \\
$0.11-0.20$ & +17.4 & +13.0 & -12.3 & -10.4 & +18.7 & -2.5 & +1.9 & +3.4 & +3.5 & +10.8 \\
$0.21-0.30$ & +13.7 & +28.0 & -16.7 & -49.0 & +99.0 & +1.4 & +5.3 & -21.5 & +10.0 & +15.3 \\
\hline
\end{tabular}



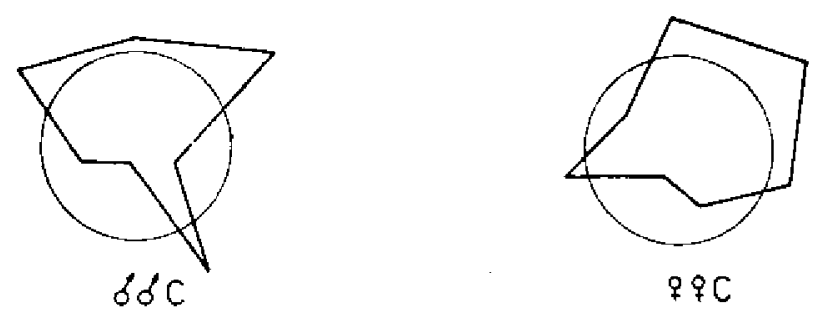

१C

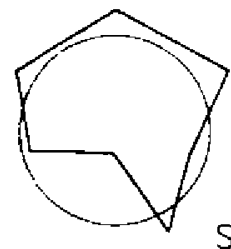

SphBip<smiles></smiles><smiles>C1C2CC3CC1CC(C2)C3</smiles>

6́́LB

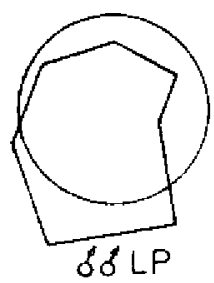

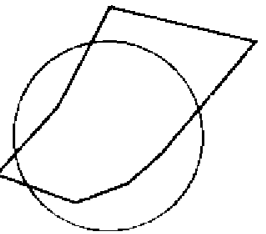

$\$ \because L-C$<smiles>[112In][131In]</smiles>

EctEct

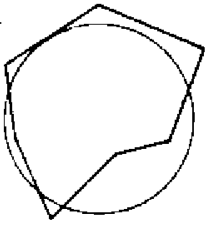

œLB

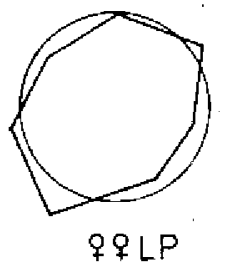

Fig. 6. Heptagons of similarity of skulls. LP - Pszczyna lowland bison, LB Białowieza lowland bison, $L-C$ - Lowland $\times$ Caucasian bison, $C$ - Caucasian bison.

Heptagons of similarity of these skulls were constructed (Fig. 6) in order to compare mean values of skull indices for the above-mentioned groups of animals. The similar elongation and narrowing of the facial part (StP, SmSm), with simultaneous elongation of the skull, in lowland $\times$ Caucasian and Caucasian bison shown in these schematic figures are remarkable. Another remarkable feature consists in the differences in shape of skulls in bison of the two sexes. These differences are fairly great in Caucasian and lowland $\times$ Caucasian bison, but small in the two lowland lines. The heptagon symbolizing the skull of Pszczyna 


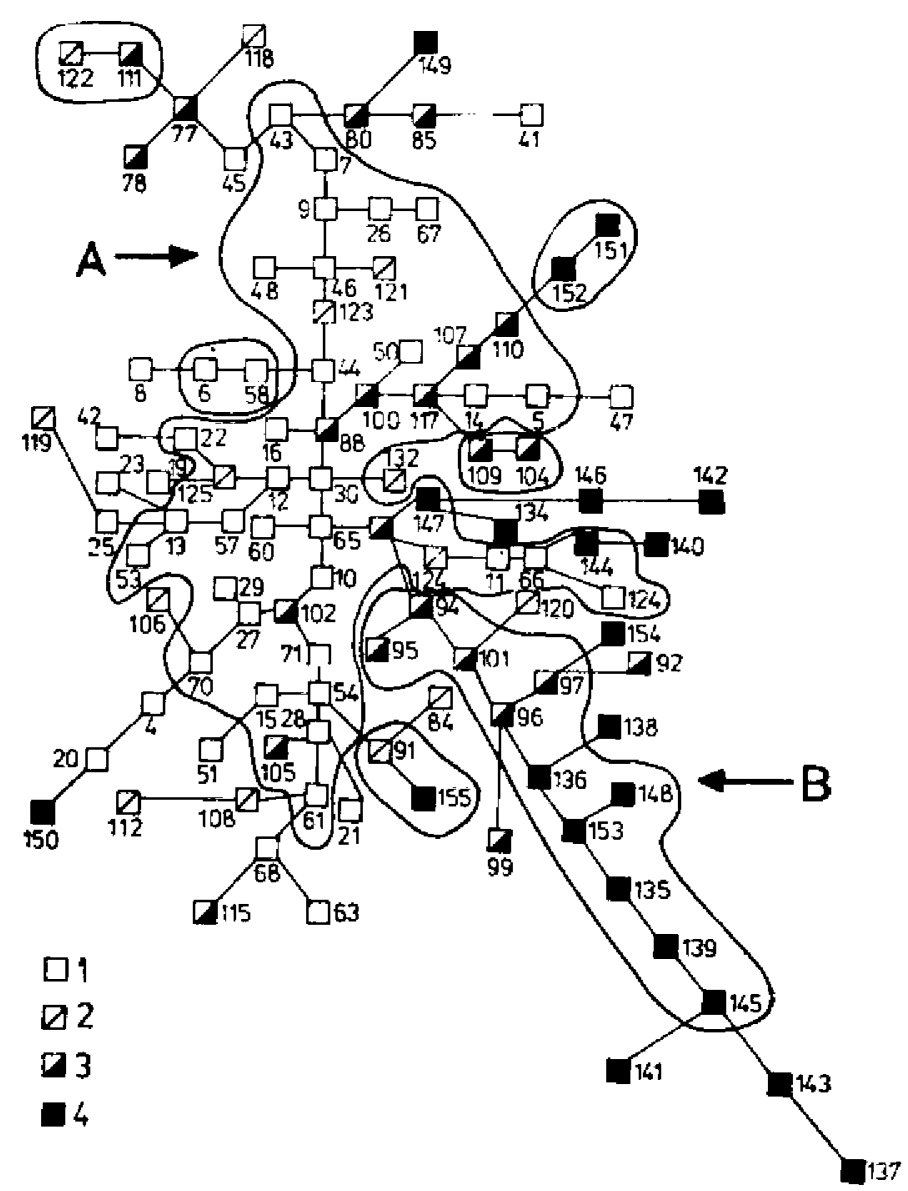

Fig. 7. Classification dendrite for skull. Explanation of symbols: 1 - Lowland bison from enclosed centres, 2 - Lowland bison from free-ranging centres, 3 Lowland $\times$ Caucasian bison from enclosed breeding centres, 4 - Caucasian bison. $A$ and $B$ - two principal series of the points. Given names of bison replaced by numbers as in Table 1.

line cows is closest to a shapely one, which explains the great similarity of this skull to the norm accepted in the sample analyzed.

The effect of inbreeding on formation of skull morphotypes is shown by their dendrite classification (Fig. 7). It embraces serjes $A$ and $B$ and many sites situated beyond them. Series A consists of 46 skulls, 26 of which belong to females and 20 to males. There are 36 skulls of lowland and 8 of lowland $\times$ Caucasian bison in this series. There are also two Caucasian bison skulls and therefore, not counting exceptions, this series is a group of lowland bison to which less inbred lowland $X$ $\times$ Caucasian and Caucasian bison were added. Series $A$ includes skulls 
Table 8

Mean values of biological similarity indices for bison skuls in groups.

\begin{tabular}{|c|c|c|c|c|c|c|c|c|}
\hline \multirow{3}{*}{ Index } & \multirow{2}{*}{\multicolumn{2}{|c|}{$\begin{array}{l}\text { Lowland } \\
\text { Pszczyna } \\
\text { line }\end{array}$}} & \multirow{2}{*}{\multicolumn{2}{|c|}{$\begin{array}{l}\text { Lowland } \\
\text { Bialowieza } \\
\text { line }\end{array}$}} & \multirow{2}{*}{\multicolumn{2}{|c|}{$\begin{array}{c}\text { Inbred } \\
\text { Lowland } \times \text { Caucasian } \\
(F>0.2)\end{array}$}} & \multicolumn{2}{|c|}{ Caucasian } \\
\hline & & & & & & & \multirow{2}{*}{$\mathbf{M}$} & \multirow{2}{*}{$\mathbf{F}$} \\
\hline & $\mathbf{M}$ & $\mathbf{F}$ & $\mathbf{M}$ & $\mathbf{F}$ & $\mathbf{M}$ & $\mathbf{F}$ & & \\
\hline $\mathrm{BP}$ & -10 & 0 & +4 & +11 & \pm 12 & +18 & +8 & +15 \\
\hline StP & -9 & +4 & -20 & +16 & +14 & $+\mathbf{3 5}$ & +32 & +28 \\
\hline BSt & -18 & -5 & +9 & -7 & -7 & -16 & -23 & +10 \\
\hline EetEct & +15 & -6 & +10 & -22 & +7 & -17 & +19 & -16 \\
\hline $\mathrm{SmSm}$ & +22 & +11 & -7 & +3 & -33 & -12 & -38 & -31 \\
\hline StN & +3 & +2 & 0 & -4 & -2 & +7 & -16 & +7 \\
\hline SphBr & $-\mathbf{3}$ & -6 & +4 & +3 & +9 & -15 & +18 & -13 \\
\hline
\end{tabular}

Fig. 8. Combined dendrite for skulls. Description of symbols like on the Figure 6 .

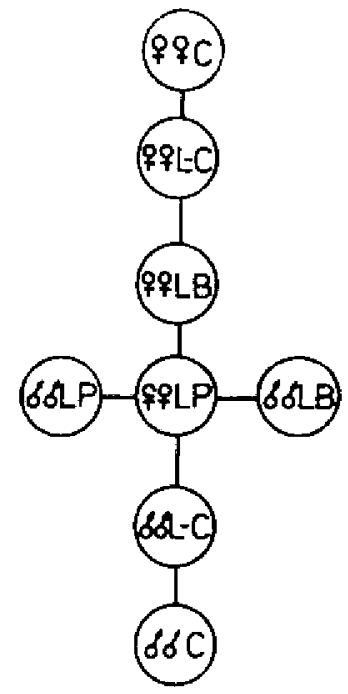

for which the mean values of the seven indices are to a great degree. close to zero.

Series B consists of 11 skulls, 6 of which belong to Caucasian and 5 to lowland $\times$ Caucasian bison with high inbreeding coefficients. This close localization is evidence of the great biological similarity of these animals. The mean values of the seven similarity indices in series $B$ differ more from zero than in series A. This is most clearly seen in the example of breadth of the splanchnocranium - SmSm $(-45)$, length of the base of the splanchnocranium - StP $(+38)$ and length. of the base of the whole skull - BP $(+20)$. It is only the indices for both heights ( $\mathrm{StN}$ and $\mathrm{SphBr}$ ) which are almost equal to zero. The. difference between mean values of indices for series $A$ and $B$ is thus. considerable.

Numerous skulls individualized in respect of shape were situated on. 
the periphery of the two series. They belong to bison of all the breeding lines, as is shown be the presence in both sample and population of a certain number of animals, the shape of whose skulls differs in a particular way from the model proportions.

The classification dendrite for skulls constructed on the basis of meam values for seven indices in different breeding lines (Table 8) shows that the distances between males and females of the two lowland lines arre far smaller than is the case with Caucasian or lowland $\times$ Caucasian bi-son (Fig. 8). A second aspect of this classification is the specific loca:lization in the dendrite of the skulls of lowland $\times$ Caucasian bison: they come closer to the skulls of the Caucasian bison than to lowland bison. It can be seen from this analysis of the dendrite that sex dimorphism of the skull is most weakly expressed in lowland bison and most clearly in Caucasian bison, lowland bison with an admixture of the blood orf Kaukasus (pedigree no. 100) occupying an intermediate position in this respect. In addition this dendrite shows clearly that lowland $\times$ Caucasiam bison are more similar to Caucasian than to lowland bison.

It can be seen from the foregoing discussion that the most plasticc in respect of effect of inbreeding on the skull are its three parameters: StP $\left(x_{1}\right), B P\left(x_{2}\right)$ and $\operatorname{SmSm}\left(x_{3}\right)$. As the change in value of these patrameters in the skulls of lowlandXCaucasian bison makes them simi-lar to the skulls of Caucasian bison, an attempt was made on the basiis of these parameters to differentiate between the skulls of lowland (Lu) and Caucasian (C) bison by means of the following Fisher's discrimitnation function:

$$
z_{L-C}=-0.006 x_{1}-0.0007 x_{2}+0.0095 x_{3}+0.21
$$

It must be borne in mind that the numeral coefficient by the indexx relating to breadth of facial part $\left(x_{3}\right)$ has the maximum absolute valuee, that is, affects the result of the equation to the greatest degree. This is evidence of the outstanding importance of this parameter as a taxornomic character in this particular taxonomy.

The value of the discrimination coefficient $z_{1,-c}$ comes within the limits of -1.14 for one of the adult Caucasian females to +1.15 forr the Pszczyna male no. 19 (Table 1). Positive values of this coefficient were envisaged for lowland bison, and negative for Caucasian bisom. It must be remembered that the more positive the discrimination coefficient in this case, the more clearly the skull expresses its "low7land" character and conversely, the more negative the coefficient the greater degree to which it reveals "Caucasian" characters.

The following shows the effect of differentiation of skulls by meanis .of the above function: with the exception of six bison nos. 20, 21, 477, 
651,63 and 68 (Table 1) all the other animals from both lowland lines reeached the anticipated positive values of the function used. This means thhat the skulls of bison forming exceptions in this division have negqative values for the discrimination coefficient and are consequently sisimilar to the skulls of Caucasian bison. In turn apart from the two skkulls of young females and one old male, for which the calculated veralues of function $z_{L-c}$ are positive, the other Caucasian bison skulls haave negative values, that is, agree with the values anticipated. It can bue seen from the foregoing that the choice of craniometric characters inn this discrimination is a fairly correct one.

The purpose of the second discrimination $z_{\mathrm{L}-\mathrm{LC}}$ is to attempt to segreegate skulls of lowland bison from lowland $\times$ Caucasian animals. The same indices were used as in the preceding function which in this case is $s$ as follows:

$$
z_{L-L C}=-0.003 x_{1}-0.005 x_{2}+0.05 x_{3}+0.042
$$

Inn this case the coefficient by index $\operatorname{SmSm}\left(x_{3}\right)$ also has the maximum atibsolute value. This confirms the important rank of this parameter alılso in distinguishing skuils of lowland bison from lowland $\times$ Caucasian annimals. Positive values of this function were anticipated for lowland bisoon and negative values for lowland $\times$ Caucasian. They come within the narrower limits than previously: from -0.92 for lowland $\times$ Caucasian feemale no. 92 to +0.62 for Pszczyna male no. 19 (Table 1). The result off this classification is as follows: among 48 skulls of lowland bison 355 exhibit positive coefficients and 13 negative, for bison no. 20, 21, $244,29, \leq 7,50,54,61,63,66,67,68,71$. The skulls of these animals anre similar to those of lowland $\times$ Caucasian bison, and the greater part of,f them (47-71) to Bialowieża bison. In the group of 28 lowland $X$ Cecaucasian bison 17 animals have skulls similar in shape to Caucasian bisison, and the remainder to lowland bison.

When comparing the values of discrimination coefficient $z_{\mathrm{L}-\mathrm{LC}}$ with innbreeding coefficient $F$, a very important relation was found between these two variables, namely the value of the discrimination coefficient delecreases with increase in inbreeding, i.e. becomes more negative (Tablole 5 , equation 7 ). This means that inbreeding within this line enhances the "Caucasian" characters of the skull.

In Bialowieża male bison, and separately in lowland $\times$ Caucasian bisoon, the size of the normalized skull $\left(M_{\mathrm{cr}}\right)$ increases proportionately wivith age (a). This relation is expressed by the considerable correlation cooefficients (Table 13). With Pszczyna males, on the other hand, no such relelation is found, which indicates some depression in the growth proceesses of their skulls. In females of all three lines there is a high degree 
of correlation between the size of the normalized skull with age, although it is lowest in the case of Pszczyna females (Table 13).

In connection with this high degree of correlation, the quotient of size of a normalized skull $\left(M_{c r}\right)$ and age (a), particularly during the middle period of postnatal development, should, on account of the straight line character of such development, have an approximately stable value. Deviations in minus from this constant value indicated by the symbol $V_{c r}$ were found in a large number of bison due to inbreeding.

Confrontation of the quotient $V_{\mathrm{cr}}$ and inbreeding coefficients $F$ in males of all three lines, collected in one group, and varying in age irom 5 to 12 years, revealed a negative correlation between these variables (Table 5 - equation 8 ). In females of the three lines, also treated as one group, varying in age from 4.5 to 15 years, a similar process takes place but even more distinctly (Table 5 - equation 9).

\subsection{Mandible}

The value of biological similarity indices of the mandible fluctuate to a greater degree round zero than in the case of skull indices. The effect of inbreeding on the shape of this bone is limited to two cases.

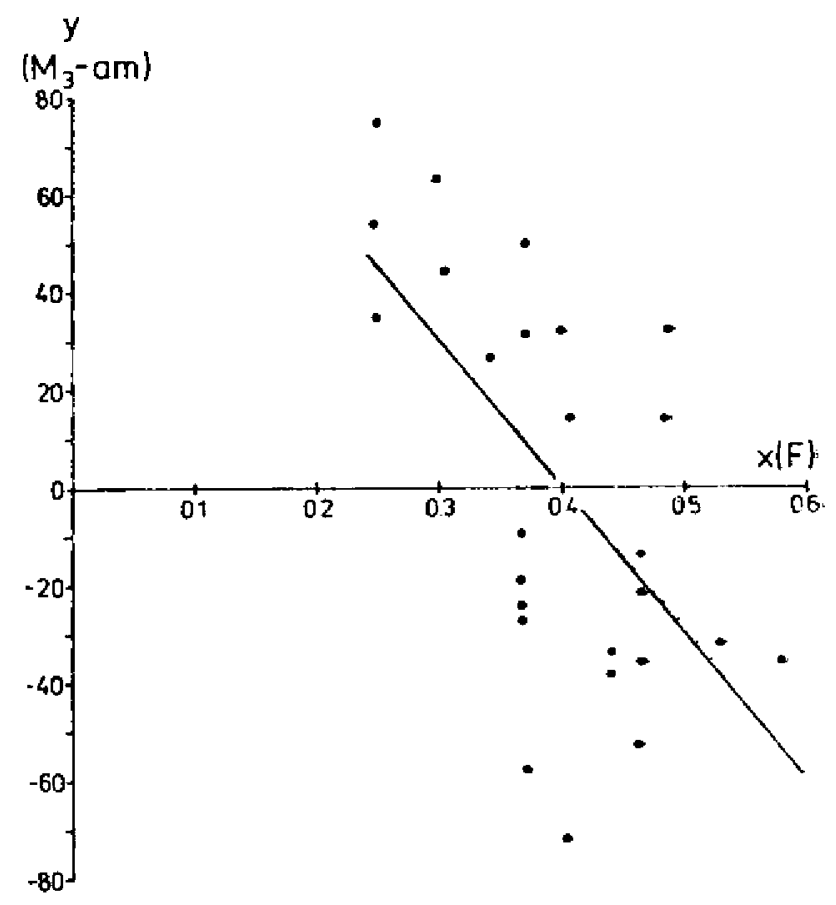

Fig. 9. Relation between linear breadth index of mandibular ramus $\left(\mathrm{M}_{3}-\mathrm{am}\right)$ and inbreeding coefficient $(F)$ in Pszczyna bison. 
The first applies to Pszczyna bison in which, together with increasing the value of the inbreeding coefficient $(F)$, there is shortening of the linear breadth of ramus mandibulae - $\mathrm{M}_{3}$-am (Table 5 - equation 10 , Table 9. Fig. 9). A second case applied to Bialowieża bison in which the

Table 9

Mean values of biological similarity indices for linear breadth of mandibular ramus ( $\left.\mathrm{M}_{3}-\mathrm{am}\right)$ of Pszczyna bison (LP) and Białowieta bison (LB) in classes defined by value of inbreeding coefficient $(F)$.

\begin{tabular}{ccc}
\hline$F$ & LP & LB \\
\hline $0.21-0.30$ & +55.8 & -18.9 \\
$0.31-0.40$ & +4.1 & +8.3 \\
$0.41-0.50$ & -25.6 & +26.5 \\
$0.51-0.60$ & -18.0 & - \\
\hline
\end{tabular}

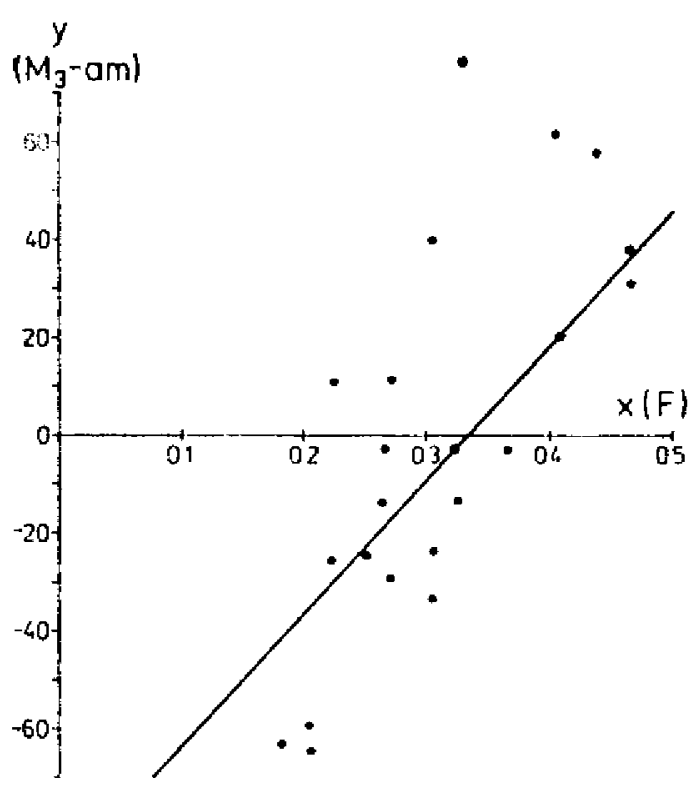

Fig. 10. Relation between linear breadth index of mandibular ramus $\left(\mathrm{M}_{3}\right.$-am) and inbreeding coefficient $(F)$ in Białowieża bison.

exactly opposite process occurs - as the result of intensive inbreeding elongation of the breadth of the ramus takes place (Table 5 - equation 11, Table 9, Fig. 10).

In lowland $\times$ Caucasian bison subject to inbreeding no significant relation was found between the mandibular index and degree of in- 
breeding. There is only a tendency to elongation of the ramus (govem) and shortening of its breadth $\left(\mathrm{M}_{3}-\mathrm{am}\right)$, as is shown by the mean values of the indices of these parameters in classes of animals defined by the value of the inbreeding coefficient (Table 6).

\subsection{Thoracic Bones}

Inbreeding does not affect the value of biological similarity indices for selected elements of the thorax, that is, does not change its shape. In lowland $\times$ Caucasian bison the relation of length index of rib. no. IX (coIX) and partial inbreeding coefficient $-F_{K}$, is close to significance, this being accompanied by shortening of the sternum - ster (Table 7). This process is synonymous with deepening and shortening of the thorax.

Correlation coefficients between the size of a normalized thorax $\left(M_{\mathrm{th}}\right)$ and age $(a)$ are considerable and always significant for both males and females in the groups examined (Table 13).

The quotients of size of normalized thorax and age $\left(V_{\mathrm{th}}\right)$ in females of the three lines, from the 4 th year of life, treated jointly are negatively correlated with the value of the inbreeding coefficient (Table 5 - equation 12). In males of all three lines the unfavourable effect of inbreeding on value of increases in the parameters of the thorax is close to significance, but could not be proved with the small number of animals in the sample.

\subsection{Bones of the Limbs}

'The change in the proportions of bones representing the four parts of the fore and hind-limbs, taking place as the result of inbreeding, has been demonstrated primarily in lowland $\times$ Caucasian bison. It was found that the change in these proportions is also caused by the degree of relationship to forbears.

Elongation of the femur - fe is observed in Pszczyna bison with a high inbreeding coefficient $(F)$ (Table 5 - equation 13, Tabie 10). When Pszczyna and lowland $\times$ Caucasian bison are combined in one group the significance of this same correlation increases ('Table 5 - equation 14). In turn in lowland $\times$ Caucasian bison the index of length of humerus (hu) and then the index of length of radius (ra) are positively correlated with the partial coefficient of inbreeding $-F_{K}$ (Table $5-$ equations 15 and 16, Table 7). It is clear from the foregoing that with increasing frequency in pedigrees of forbears having Cauiasian bison genes, elongation of both the humerus and radius takes place in progeny of the lowland $\times$ Caucasian line. 
A further change in proportions in lowland $\times$ Caucasian bison is elongation of the stylopodial part in the pelvic iimb, represented by the femur (fe), which is the consequence of increased inbreeding expressed by the second partial coefficient $\left(F_{\mathrm{Pl}}\right)$ estimated on the basis of presence in forbears' pedigrees of the Pszczyna line only (Table 5 equation 17). Finally length of the autopodium of the fore limb (aua) of lowland $\times$ Caucasian bison is an example of a parameter affected by relationship to Plebejer $\left(R_{\mathrm{Pl}}\right)$ and Kaukasus $\left(R_{\mathrm{K}}\right)$. Shortening of the

Table 10

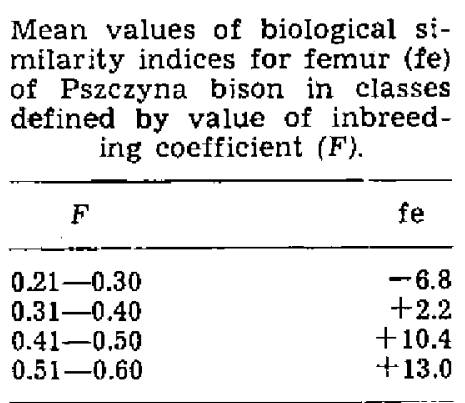

Table 11

Mean values of biological similarity indices for fore autopodium (aua) of Lowland $X$ Caucasian bison in classes defined by value of the coefficient of relationship to Plebejer $\left(R_{P !}\right)$.

\begin{tabular}{cr}
\hline$R_{P l}$ & \multicolumn{1}{c}{ aua } \\
\hline $0.0-10.0$ & +27.4 \\
$10.1-20.0$ & +1.2 \\
$20.1-30.0$ & +4.4 \\
$30.1-40.0$ & -46.0 \\
\hline
\end{tabular}

above-mentioned autopodium occurs together with increase in relationship to the first forbear (Table 5 - equation 18, Table 11), while increase in relationship to the second brings about the reverse process (Table 5 - equation 19, Table 12), that is, elongation of this part of the limb.

Comparison of the values of eight biological similarity indices for the limbs of lowland and lowland $\times$ Caucasian bison shows that the greatest differences apply to indices of scapular length - sc $\left(x_{1}\right)$, the mean value of which is greater in lowland bison, and indices of radius length - ra $\left(x_{2}\right)$, which on an average is greater in lowland $\times$ Caucasian bison. 
Fisher's function based on these taxonomic characters gives the equation:

$$
z_{1-I, C}=+0.0089_{1} x-0.0143 x_{2}+0.0120,
$$

in which it is assumed that positive values relate to lowland bison (L) and negative - lowland $\times$ Caucasian (LC). It can be seen from the construction of this function that the radius is of greater importance in this discrimination $\left(x_{2}\right)$ than the scapula $\left(x_{1}\right)$. This discrimination

Table 12

Mean values of biological similarity indices for fore autopodium (aua) of Lowland $x$ Caucasian bison in classes defined by value of the coefficient of relationship to Kaukasus $\left(\boldsymbol{R}_{K}\right)$

\begin{tabular}{cr}
\hline$R_{K}$ & \multicolumn{1}{c}{ aua } \\
\hline $1.1-2.0$ & -23.0 \\
$2.1-3.0$ & -5.1 \\
$3.1-4.0$ & +2.3 \\
$4.1-6.4$ & +39.0 \\
\hline
\end{tabular}

Table 13

Correlation coefficients between value of normalized magnitude of skeleton $(M)$ and age (a). Non-significant correlations were omitted. Numbers above and below the line are related to males and females, respectively.

\begin{tabular}{|c|c|c|c|}
\hline \multirow{2}{*}{$\begin{array}{l}\text { Part of } \\
\text { skeleton }\end{array}$} & \multicolumn{3}{|c|}{ Line } \\
\hline & Pszczyna & Bialowieża & Lowland $\times$ Caucasian \\
\hline \multirow[b]{2}{*}{ Skull $\left(M_{\mathrm{er}}\right)$} & & +0.6161 & $+0.735^{2}$ \\
\hline & $+0.765^{2}$ & $+0.889^{2}$ & $+0.893 *$ \\
\hline \multirow[b]{2}{*}{ Thorax $\left(M_{t h}\right)$} & $+0.867 \mathrm{a}$ & $+0.746^{x}$ & $+0.681 *$ \\
\hline & $+0.857^{2}$ & $+0.708^{2}$ & $+0.772^{2}$ \\
\hline \multirow{2}{*}{ Limbs $\left(M_{m e}\right)$} & & & $+0.823=$ \\
\hline & +0.6632 & $+0.555^{3}$ & $+0.747^{\prime}$ \\
\hline
\end{tabular}

$\pm 0.01<p \leqslant 0.05,90.001<p \leqslant 0.01$.

was satisfactory for lowland bison, since out of 61 animals only 7 obtained negative values of this function, i.e. bison no. $4,8,9,10,11$, 44, 50 (Table 1), while the decided majority belonged to bison having "lowland" characters of the limb bones. Among lowland $\times$ Caucasian bison just over half $(57 \%)$ obtained the anticipated negative values for the discrimination coefficient $z_{\mathrm{L}-\mathrm{LC}}$ classifying them on the side of Caucasian bison. The bones of the limbs of the other lowland $\times$ Cau- 
casian bison with positive values for this coefficient do not differ in respect of proportions from the skeletons of lowland bison.

Comparison of the value of coefficient $z_{\mathrm{L}-\mathrm{LC}}$ with the animals' age (a) showed a relation between these variables. Thus for Pszczyna and Bialowieża females taken as one group, the value of this coefficient increases with age (becomes more positive), which means that the specific characters for the limb bones of lowland bison become more distinct in older animals. In males this relation has the following value: $r=+0.352(p \leqslant 0.01)$, and in females: $r=+0.510(p \leqslant 0.01)$.

The size of the normalized limb $\left(M_{\text {me }}\right)$ and thus in a certain sense the height of bison, is correlated with age (a) in some animals. The coefficients of this relation, apart from males of the two lowland lines, are highly significant in the remaining bison (Table 13).

\subsection{The Skeleton as a Whole}

Inbreeding was not found to change proportions between the dimensions of length of the axial skeleton and length of limbs. It was however proved that the quotient of size of the normalized skeleton and age $\left(V_{\text {sce }}\right)$ has a significant connection with degree of inbreeding. In females of the three lines aged from 5 to 15 years this process has been fully documented (Table 5 - equation 20), while there are distinct signs of this in males.

\section{DISCUSSION}

Inbreeding in the lowland bison population appeared with the start of restitution of this species after its almost complete liquidation at the beginning of the present century. Its high level in the renewed herd was due both to the small number of bison used for reproduction (Plebejer, Planta, Bizerta and Biscaya) and also from the presence among them of only one male.

Breeding from closely related bison has previously been resorted to. An example of this is, inter alia, breeding in reserves set up at Pszczyna in Silesia in 1865 by Prince von Pless, from which contemporary Pszczyna bison originate, as the few examples existing today and the two other lines - Białowieża and lowland $\times$ Caucasian, forming almost the whole of the present world herd of this species.

The unfavourable results of inbreeding, defined as inbreeding depression, were probably not so disastrous to the Pszczyna bison, since their breeding, despite reserve conditions, developed successfully as is shown by shoots of these animals organized in the game reserve at Pszczyna and also their transfer to other reserves of this type (Sztolc26 - Acta Theriologica 
man, 1923, 1924; Czudek, 1930). Nevertheless the heterozygotic pair Plebejer-Planta may have originated from parents related to each other and transmitted a certain level of homozygosity to the Pszczyna line restituted after World War I.

The attempt at restoring the lowland bison at Bialowieża by means of the three siblings purchased in Sweden: Biserta, Biscaya and Björnson (pedigree no. 186), whose close forbears originated directly from the Białowieża free-ranging herd, ended in failure. The bison Björnson introduced to Bialowieża was killed when fighting during the mating season by the Bialowieża $\times$ Caucasian hybrid Borusse (Krasiński, 1978). In order to save the situation, in view of the lack of another lowland bull, the Swedish cows purchased were covered by Borusse, thus initiating the lowland $X$ Caucasian line. A historic part in restitution of the three lines was next played by two males, halfbrothers - Plisch and Pluvius II - close descendants of Plebejer and Planta. Plisch in covering Biserta and Biscaya, and its own daughters from these matings, finally created the Białowieża line, and simultaneously by covering Białowieża $\times$ Caucasian cows, became the next reproducer after Borusse in the lowland $\times$ Caucasian herd. Finally Pluvius II became the chief reproducer, after Plebejer and Pless (pedigree no. 195) of the Pszczyna line.

In the process of the historical development of other representatives of Bison similar decline in population numbers might also have taken place, probably caused by geoclimatic cataclysms or isolation of the animals on the periphery of their range. The genetic drift and inbreeding due to such population reduction are probably responsible for certain phenotypic deviations in the bones of bison, relating to, inter alia, structure of teeth, splanchnocranium, nuchal surface, cornual process and limbs (McDonald, 1981). It is considered that some tooth pathologies in bison of prairie populations of the early Holocene are in fact consequences of inbreeding. In small inbred bison populations recessive characters could have appeared in phenotypes and in extreme cases forming the consequences of persisting inbreeding chaos, lead to weakening of vitality (McDonald, 1981).

The above remarks may also apply to European bison, whose numbers and range have been greatly reduced during the last few centuries even when the effect of the anthropogenic factors in this connection was still negligible. Flerov (1979) also supports this view.

As mentioned in the introduction to the present study, no separate studies have yet been undertaken dealing with changes in the skeleton of the European bison caused by inbreeding. Although there are several papers concerned incidentally or directly with the pathology of 
the skeleton of this species or quantitative deviations within this skeleton (sacralization, lumbalisation) which could come within the limits of population variations (Juśko, 1953; Pilarski, 1956; Pilarski \& Roskosz, 195'; ; Empel \& Roskosz, 1963; Kobryń \& Kobryńczuk, 1973, 1976), none of these variations and deviations have been connected with the effect of inbreeding, but only occasionally with relationship in direct line. The case is further complicated by the fact that there are no such variations in the majority of lowlandXCaucasian bison, which are also products of inbreeding.

The results of breeding closely related animals on reproduction and vitality of European bison have been better investigated. Studies made in recent years have shown that inbreeding of these animals may proceed in two directions - inbreeding to lethal or non-lethal genes. In the first case the results are known, whereas in the second the vitality of European bison is observed on an equal footing with non-inbred animals (Slatis, 1960; Onopiuk, 1984). It was previously assumed that the process of totalling characters both positive and negative might take place in the inbred Silesian bison (Grochmalicki, 1933).

Close inbreeding of domestic animals has shown that inbreeding depression reduces fertility and fecundity to the greatest degree (Johansson \& Rendel, 1968). Analysis of the number of deaths among newborn or stillborn bison calves, carried out on the basis of the European Bison Pedigree Books (Żabinski, 1947-6̄̄; Żabiński \& Raczyński, 1972) shows that the percentage of males among highly inbred dead calves is greater in these circumstances than that of females.

Low inbreeding - up to $10 \%$ - is most harmful to European bison. With this level of homozygosity they live for a period three times shorter than an average, non-inbred animal, whereas inbreeding of $30-20 \%$ does not affect the lifespan (Onopiuk, 1984). The case is similar with other parameters of European bison biology, for instance with age of first calving in females, length of time between calvings, times of oestrus and calvings etc. All these parameters are almost always altered by low inbreeding, although as inbreeding increases deviations of this kind are no longer observed (Onopiuk, 1984). An example of this is the highly inbreed bull Podbipięta (no. 66 - Table 1), which during its long life fathered 32 calves. Inbreeding may, however, cause sterility in bulls without affecting their length of life, as in the case of Popas (no. 57 - Tables 1 and 2), which was set free while young. Some authors have failed to perceive degenerative symptoms in an inbreeding herd of European bison (Scibor, 1960). In this connection Frankel and Saule (1981) have put forward an interesting hypothesis. On the basis of two species - Elephurus davidianus, among Cervidae, and 
the European bison, Bison bonasus - of Bovidae, they assume that many of the fatal alleli may be eliminated by very slow inbreeding accompanied by selection. An essential condition is, however, a long period during which relatively small populations exist, but are sufficiently large to prevent the tragic results of inbreeding.

Opinions on the subject of late autumn calvings occurring among European bison are controversial. Jaczewski (1958) states that relatively the greatest number of such calvings are encountered in Pszczyna bison, in which they are the result of inbreeding. The observations made by Krasiński and Raczyński (1967) during the period from 1954-1965 showed that free-ranging European bison cows produce young during the jeriod from May to September, whereas in reserves this takes place from April to December. Other authors consider autumn calvings as a sign of progressive domestication of the European bison consisting, inter alia, in its reproduction biology becoming similar to that observe 1 in domestic ruminants (Czudek, 1930; Gill, 1967; Krysiak, 1967; Krasiński, 1976).

The disastrous results of inbreeding in European bison may appear under unfavourable habitat conditions (Onopiuk, 1984). Such conditions include insufficient fodder (Krasinski, 1978) and helminthiasis of the alimentary tract (Dróżdż, 1961, 1967). The harmful results of long-term inbreeding in the case of European bison may be eliminated by selection of animals carrying characters of reduced vitality and fecundity (Krasiński \& Raczyński, 1967).

Variation in skull parameters in the group including lowland and lowlon $d \times$ Caucasian bison is considerable in comparison with Caucasian bison (Table 4) and North American bison. For example the variation in skuil length of the contemporary European bison is 3-4 times greater than in $B$. caucasicus or $B$, $b$, athabascae. Interorbital breadth differs to an even greater extent in this respect. An exception is formed by the skulls of $B$. latifrons and $B$. alaskensis, in which variation is very great (McDonald, 1981). It follows from this that the skull of the lowland European bison has not as yet an established morphotype, as is also shown by the high percentage of skulls lying outside the group $\mathrm{A}$ in the dendrite (Fig. 7).

Some researchers consider that variation in the skull parameters of mammals living in captivity is greater in males than in females, whereas under natural habitat conditions the reverse applies (Pavlinin, 1362). This remark may also apply to the bison examined, almost all of which originated from enclosed breeding centres.

The great variation in skull parameters of contemporary Eurosean bison, the majority of which are inbred animals, is contrary to the prin- 
ciple according to which inbreeding increases genetic homogeneity and morphological similarity of individuals in a population (Hutt, 1964; Srb et al., 1965; Maciejowski \& Zięba, 1962).

In studies on the evolution of bison considerable importance is attached to size and formation of processus cornuales (McDonald, 1981). The choice of these elements of the skeleton is no accident, since they are those best preserved in archeozoological findings, and are sometimes the only available components of the skull. Their usefulness in taxonomy as a diagnostic character has both supporters and antagonists. Allen's horn theory (1876) that each subsequent species of American bison has smaller horns than its forbears, encountered the criticism contained in Guthrie's synthetic theory (1970 - after McDonald, 1981). Guthrie considers that the taxonomic value of processus cornuales is over-estimated. It follows from his arguments that their growth is not synchronized with increase in skull dimensions, while growth is most intensive at the time when the skull attains a size close to final size.

Studies on processus cornuales in contemporary lowland European bison revealed their great variability and occasionally asymmetry, so that their shape cannot form a basis for defining their appurtenance either to sex or to breeding line (Empel, 1962), neither was any correlation found between the characters of processus cornuales and degree of inbreeding.

The choice of seven skull parameters as taxonomic characters was by no means accidental in the present studies, since it was intended by their use to define the shape of the skull in three basic geometrical planes, in a similar way to that done by other craniologists (Perkal, 1958; Empel, 1962). It was found that the changes in shape of the skull taking place as the effect of inbreeding are linear in character, that is, a character in which increase in the values of the inbreeding coefficient correspond to the proportional increase in the values of biological similarity indices, which is in conformity with the law of quantitative genetics stating that change in an average population is in direct proportion to degree of inbreeding (Srb et al., 1965).

The present studies showed that inbreeding does not change the shape of the skull in lowland bison of the Pszczyna and Bialowieza lir.es, regardless of its degree. On the other hand change in the skull yroportions of inbred lowland $\times$ Caucasian bison applies primarily to narrowing or elongation of its facial part, which is equivalent to reconstruction of the shapes of the skull in Caucasian bison.

Earlier studies have shown that lowland $\times$ Caucasian bison, particularly females, have relatively longer skulls than lowland bison (Empel, 
1962). The detail differentiating the skulls of pure-bred Caucasian bison and lowland bison is, according to Koch (1932), Empel (1962) and Pucek (1985) tuber malare, more weakly formed in the former. Empel (1962) and later Flerov (1979) draw attention to the presence in the skulls of lowland bison of the characteristic frontal tuberosity, which is absent in Caucasian bison and the majority of lowland $\times$ Caucasian bison. Flerov (1979) also draws attention to the lower facial part of the skull in Caucasian than in lowland bison. This difference has not been confirmed in our studies. The height of the splanchnocranium ( $\mathrm{StN}$ ) did not appear even once as a character discriminating between skulls of lowland and Caucasian bison, whereas the most important diagnostic character in this discrimination is the breadth of the splanchnocranium and next its length ( $\mathrm{SmSm}$ and StP).

Among factors affecting the size and shape of the nasal cavity in mammals is climate. The northern forms of bison, as opposed to the southern forms, have a relatively longer and narrow nasal cavity (Flerov, 1979). This is connected with the development of conchae nasales, warming and moistening inhaled air.

On the basis of skeletal and dental characters bison are allocated to the forest or steppe form (Kowalski, 1967; Flerov, 1979; McDonald, 1981). Among the former are B. b. athabascae and B. bonasus bonasus, and the latter - B. b. bison. Bison bonasus caucasicus could be the steppe form adapted to a dry mountain climate.

Elongation of the nasal cavity is also the effect of elongation of conchue ethmoidales, due to the better developed smell receptor. Poplewski (1948) considers that in circumstances when the organ of sight cannot meet requirements in biocommunication, the organ of smell adapts itself to intensified demands. On account of natural obstacles to visual orientation such as mountains, labyrinthus ethmoidalis in the Caucasian bison may in lact be better tormed than in lowland bison.

Dendrite classification differentiated between two skull morphotypes -- one for lowland bison, the other for Caucasian and inbred lowland $\times$ Caucasian bison. The skulls of inbred lowland bison do not differ in respect of shape from those of bison not subject to inbreeding, wrile considerable similarity was found in the skulls of inbred lowland $X$ Caucasian bison to those of pure-bred Caucasian bison. Dendrite classification has shown that inbreeding in the lowland herd weakens sex dimorphism in the skull and restores the "Caucasian" shapes to lowland $\times$ Caucasian bison.

Fisher's discrimination provides proof of the existence in the present lowland bison population of animals having skulls similar to those of Caucasiau bison. 
The basic difference in the shape of the mandible in forest and steppe bison is in the shaft, which in the former is low and in the latter high, giving greater strength during chewing of ligneous steppe vegetation (Flerov, 1979). The relatively low shaft of the mandible is characteristic of the lowland bison (Pucek, 1984), which together with other characters qualifies it as an inhabitant of forest ecosystems (Kowalski, 1967). The height of the mandible in European bison is however dependent on the age of the given individual (Empel, 1962). The hypselodont teeth in these animals come out from their alveoli during wear and consequently lower the tooth alveolar margin of the shaft. The shaft becomes relatively lower or higher depending on the kind of plant food eaten. Adaptation of this kind is observed in Pleistocene and later Holocene bison as the result of passing from forest to steppe forms (Flerov, 1979). The present studies have shown that with Pszczyna line bison the linear breadth of the mandibular ramus becomes shorter with increasing inbreeding $\left(\mathrm{M}_{3}-\mathrm{am}\right)$ whereas in Białowieża bison the reverse applies. Either process is difficult to interpret - the stimulus is the same and reaction different. The basis of the differences may be the averagely greater degree of inbreeding in Pszczyna bison than in these animals from Białowieża, or the longer initial period of inbreeding in the former expressed in the greater number of generations.

The mandible is a bar-like structure subjected to the action of chewing muscles, and is most exposed to deformation in the place where the shaft passes into the ramus. The breadth of the mandible in this place $\left(\mathrm{M}_{3}\right.$-am) is variable and is most closely correlated with the degree of biting force, and consequency with hardness of food. It is for this reason that shortening of the breadth of the mandibular ramus, due to inbreeding in Pszczyna bison, may also indicate a change in the shape of the mandible in the direction of forest forms of bison and the reverse process - to reconstruction of the mandible in steppe forms.

With intensification of inbreeding elongation of the mandibular ramus takes place in lowland $\times$ Caucasian bison. Such elongation increases the moment of force of chewing muscles, and consequently greater biting force may be obtained without altering muscle strength. Elongation is, inter alia, the results of raising of the temporomandibular articulation of ruminants. It is justifiable to assume that the Caucasian bison had an elongated mandibular ramus on account of feeding to a great degree on ligneous food, and that this character is reproduced by inbreeding in lowland $X$ Caucasian bison.

The curves of ribs in extinct bison were shaped by their habitat. Forest bison were distinguished by a flattened thorax, which made it 
easier for them to move through dense tree stands (Rešetov \& Suhanov, 1979). As a result of these transformations of the thorax the animals gained in height and had a narrower space between the thoracic limbs and higher positioning of the body's centre of gravity. Formation of the thorax in steppe bison proceeded in the opposite direction. A barrel-shaped thorax, legs more widely set apart and lowered centre of gravity ensured their better locomotor technique under conditions of the savannah and steppe.

Kobryn's studies (1973) showed that the angular value of the curvature of ruminants' ribs increases with age and also that the thorax is more arched at the sides in species with smaller body measurements. The thorax in the American bison, B. b. bison, a representative of steppe-prairie bison, is more barrel-shaped than in the lowland bison an inhabitant of forests. The present studies proved that the length of the costal bones in comparison with other elements of the skeleton, are elements subject to great variation, due to their free development. The low degree of variation in length of rib $\mathrm{V}$ is however worthy of notice, and this is most certainly connected with the small movements of the thorax at this level on account of the close vicinity of the heart.

No significant connections were, however, found between length of selected elements of the thorax and degree of inbreeding. It was only found that there are tendencies to elongation of rib $1 \mathrm{X}$ and shortening of the sternum in inbred lowland $\times$ Caucasian bison. The lack of exact data makes it impossible to determine definitely if these changes in the shape of the thorax cause by inbreeding tend in the direction of reproducing its shape in the Caucasian bison.

The basic material in comparative papers on evolution of the limbs in Bos and Bison consists primarily of the long bones (Calkin, 1960, 1965; Lasota-Moskalewska, 1980; McDonald, 1981). The relative lenghts of these bones or parts of the limbs depend in ungulates on several factors, one of which is the animal's age (Johansson \& Rendel, 1968). In newborn animals the autopodial parts of the limbs are relatively longer than in adults, while the length of zonopodial parts of limbs is the reverse. This is because growth in length of the zonopodial parts of limbs in postnatal life is more intensive than the moderate growth of the peripheral parts. Among the latter the bones of metapodia have epiphysial cartilage in only one epiphysis, like the proximal and medial phalanges, whereas the other components i.e. the tarsal or carpal bones and distal phalanges, have none of these cartilages (Empel \& Roskosz, 1963). The absence of these cartilages in some elements of autopodia conditions the slower growth rate of these parts as compared with others. 
A second factor affecting the proportions of the limb bones is sex. It was found that the metapodia of male bison are relatively shorter than in females (Table 13, 14).

Finally the mammal's body weight is important, since it imposes a burden on the limbs. According to Gambarjan (1972) and McDonald

Table 14

Relative lengths of bones of the limbs and sum total of their absolute length $(\mathrm{mm})$ in the thoracic limb $\left(S_{t h}\right)$ pelvic $\operatorname{limb}\left(S_{p}\right)$ in Lowland and Lowland $\times$ Caucasian bison.

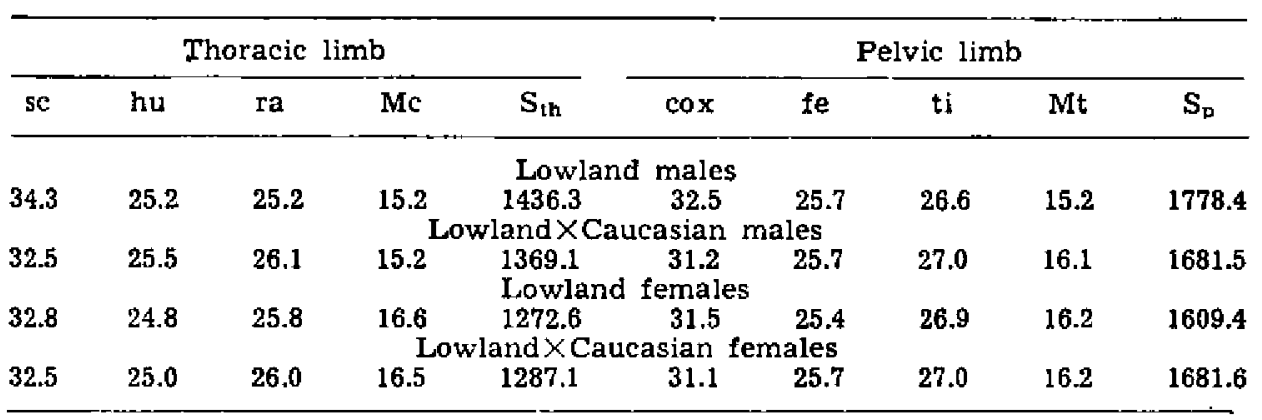

Table 15

Relative lengths of bones of the limbs and sum total of their absolute lengths $(\mathrm{mm})$ in the thoracic limb $\left(\mathbf{S}_{\mathrm{t}}\right)$ and pelvic limb $\left(\mathbf{S}_{\mathrm{b}}\right)$ of some representatives of the genus Bison after McDonald (1981). Data for forms B. bonasus after author's own studies.

\begin{tabular}{|c|c|c|c|c|c|c|c|c|}
\hline \multirow{2}{*}{ Species } & \multicolumn{4}{|c|}{ Thoracic limb } & \multicolumn{4}{|c|}{ Pelvic limb } \\
\hline & hu & ra & Mc & $S_{t h}$ & fe & ti & Mt & $\mathbf{S}_{\mathrm{p}}$ \\
\hline \multicolumn{9}{|c|}{ Males } \\
\hline B. latifrons & 38.9 & 37.1 & 24.0 & 1033.5 & 38.7 & 36.8 & 24.4 & 1243.4 \\
\hline B. a. antiquus & 38.2 & 37.0 & 23.9 & & 38.5 & 36.9 & 24.6 & 1114.9 \\
\hline B. a. occidentalis & 38.8 & 37.3 & 23.9 & 920.5 & 37.5 & 37.4 & 25.1 & 1077.5 \\
\hline B. b. athabascae & 38.4 & 36.9 & 24.7 & 92 & 37.9 & 37.3 & 24.8 & 1111.3 \\
\hline$B$ b. bison & 38.2 & 37,6 & 24.2 & 852.7 & 37.8 & 36.9 & 25.3 & 1007.8 \\
\hline$B$, bonasus & 38.4 & 38,4 & 23.2 & 940 & 38.0 & 39.5 & 22.5 & 1200.3 \\
\hline$B$, bonasus $\times$ B. caucasicus & 37.7 & 38.7 & 23.6 & 924.4 & 37.3 & 39.2 & 23.5 & 1157.7 \\
\hline \multicolumn{9}{|c|}{ Females } \\
\hline B. latifrons & 36.2 & 37.7 & 26.1 & 952.3 & 38.2 & 36.4 & 25.4 & 1123,5 \\
\hline B. a. antiquus & 38.5 & 36.8 & 24.6 & 892 & 37.9 & 36.9 & 25.2 & 1056.9 \\
\hline B. a. occidentalis & 38.0 & 37.1 & 24.9 & & 37.1 & 36.6 & 26.3 & 989.7 \\
\hline B. b. athabascae & 36.3 & 37.4 & 26.3 & 837.0 & 36.7 & 36.6 & 26.7 & 987.0 \\
\hline B. b. bison & 36.8 & 37.7 & 25.5 & 778.2 & 37.1 & 36.4 & 26.5 & 923.0 \\
\hline B. bonasus & 37.0 & 38.4 & 24.6 & 855.1 & 37.2 & 39.3 & 23.5 & 1102.2 \\
\hline$B$. bonasus $\times B$. caucasictus & 37.2 & 38.5 & 24.3 & 869.0 & 37.3 & 39.1 & 23.6 & 1122.9 \\
\hline
\end{tabular}

(1981) the bones of the metapodial parts undergo shortening with increasing body dimensions in ungulates. All the above factors contribute to variations in length of the long bones or whole parts of the limbs. It can be seen from the data given in tables 4 and 15 that variations. 
in length of a part of a limb are the lesser, the more peripheral the given part. Exceptions to this are B. b. athabascae and B. b. bison.

Variation in length of the different bones of the limbs in the European bison is considerable in comparison with the majority of American bison (Table 15). It is particularly great in lowland $\times$ Caucasian bison, thus providing evidence of the unstabilized model of the proportions of limbs in these animals, probably influenced by inbreeding.

Analysis of the coefficients included in table 15 shows that like the European bison, the North American early Holocene taxon - B. antiquus occidentalis - was distinguished by considerable variation of the parameters of the bones of its limbs. The question then arises as to

Table 16

Coefficients of variation (CV) of length of limb bones of some representatives of the genus Bison after McDonald (1981). Data for forms B. bonasus after author's own studies.

\begin{tabular}{|c|c|c|c|c|c|c|c|c|}
\hline Species & se & hu & ra & Mc & $\operatorname{cox}$ & fe & $\mathrm{ti}$ & Mt \\
\hline \multicolumn{9}{|c|}{ Males } \\
\hline B. latifrons & - & $\mathbf{3 . 7}$ & 2.6 & 3.3 & - & 0.5 & 2,4 & 2.2 \\
\hline B. a. antiquus & - & 4.1 & 2.2 & 3.0 & - & 3.2 & 3.5 & 3.0 \\
\hline B. a. occidentalis & - & 5.9 & 4.2 & 3.9 & - & 4.4 & 4.3 & 3.7 \\
\hline B. b. athabascae & - & 1.8 & 4.1 & 1.8 & - & 2.0 & 2.7 & 3.0 \\
\hline B. b. bison & - & 3.4 & 2.8 & 3.4 & - & 2.7 & 2.7 & 3.0 \\
\hline B. bonasus & 7.2 & 5.4 & 5.8 & 3.3 & 7.7 & 4.4 & 4.4 & 3.6 \\
\hline$B$. bonasus $\times B$. caucasicus & 17.2 & 10.1 & 8.3 & 3.5 & 15.3 & 9.8 & 8.0 & 4.0 \\
\hline \multicolumn{9}{|c|}{ Females } \\
\hline B. latifrons & - & - & 2.5 & 2.5 & - & 3.7 & 0.2 & 1.7 \\
\hline B. a. antiquus & - & 4.0 & 4.5 & 3.1 & - & 3.8 & 2.6 & 3.2 \\
\hline B. a. occidentalis & - & 6.6 & 5.2 & 3.5 & - & 4.6 & 5.2 & 3.6 \\
\hline B. b. athabascae & - & - & - & - & - & - & - & - \\
\hline B. b. bison & & 3.0 & 3.1 & 3.4 & - & 2.9 & 3.0 & 3.2 \\
\hline B. bonasus & 10.6 & 7.1 & 5.9 & 2.7 & 8.9 & 5.6 & 5.2 & 2.8 \\
\hline$B$. bonasus $\times B$. caucasicus & 10.1 & 6.2 & 6.6 & 3.2 & 6.7 & 3.0 & 2.5 & 2.3 \\
\hline
\end{tabular}

whether considerable variation is a good or bad prognosis for further development of the species. $B$. $b$, occidentalis, referred to above was the forbear of contemporary bison: $B$. $b$. bison and $B$. b. athabascae (until 1928), whereas the broad-headed $B$. latifrons, which was characterized by lesser variation in skeletal parameters, did not prolong its existence in any Holocene form (McDonald, 1981), hence the conclusion that considerable individual variation in a population is a good prognosis for the development of the species.

The present paper is intended, inter alia, to prove that inbreeding may alter the proportions of the limb bones in European bison - hybrids of bonasus and caucasicus. These changes apply chiefly to the forelegs 
in respect of the relative shortening of the scapula and elongation of the other parts forming the bone structure of the limb. All this follows on increasing intensification of inbreeding in the lowland $\times$ Caucasian lire (Table 13).

The fragmentary data given in the paper by Rešetov \& Suhanov (1979) suggest that the Caucasian bison had a relatively shorter scapula than the lowland form. An indirect method of estimating the length of this bone may be the degree of development of regio interscapularis, also called the hump, which as stated by some authors was smaller in the Caucasian bison than in the lowland form (Wróblewski, 1927; Flerov, 1932; Zablocki, 19ட8; Rešetov \& Suhanov, 1979).

The shape of regio interscapularis is a peculiarity encountered in other species of Bison and Bos. When examining the skeleton of domestic cattle and European bison no confirmation was found for assumptions that there is a positive correlation between head size and height of spinous processes of the first thoracic vertebrae, which are the bony structure of the hump (Koch, 1932; Roskosz \& Empel, 1962).

Szarski (1982) considers that a well-formed regio interscapularis is a characteristic of ungulates living in lowlands, since in his opinion this structure makes raising the head easier while cropping grass. Mountain animals feeding on hillsides do not lower their heads so much, hence their regio interscapularis is less clearly developed.

Rešetov \& Suhanov (1979) in justifying a similar opinion draw attention to the strong development of spinous processes on the thoracic vertebrae, providing elastic stiffening of this part of the vertebral column. Such stiffening is conditioned by yellow ligamenta interspinalia connecting adjacent spinous processes. These ligaments are stretched when the animal lowers its head, and accumulate in themselves on account of this elasticity a certain amount of potential energy which is liberated while the head is being raised, assisting the respective muscles in this task. Therefore the bigger the hump i.e. the greater the accumulation of interspinal ligaments, the more effective the biomechanics of the vertebral column in respect of such movements.

This mechanical property of the regio interscapularis is also employed by European bison when fighting with their horns, which is often observed among rival bulls (Wróblewski, 1927). This is one of the explanations of why female bison have a relatively lower hump than bulls (Pucek, 1985). In comparison with bulls they exhibit a less aggressive attitude to other animals in the herd. Rešetov and Suhanov (1979) consider that steppe bison have a better formed hump than forest bison.

Certain resemblances in changes in proportions of the long bones in 
the thoracic limb in lowland $\times$ Caucasian bison may also be encounter$\epsilon \mathrm{d}$ in the hind leg (Table 13). This is manifested in elongation of the femur, representing the same part of the limb as the humerus. Also in comparison with lowland bison the os coxae, in a similar way to the scapula, becomes shorter.

The coefficient of relationship to forbears $(R)$ as an independent variable enters for the first time into definite connection with the value of the biological similarity index in the case of the bones of the limbs. It therefore represents a genetic factor, which in studies of this type plays a less important part that the inbreeding coefficient $(F)$.

When comparing the mean values of the biological similarity indices of length of limb, spine and skull with the inbreeding coefficient no significant correlations were found, although this was probably due to being unable to record them on account of the small number of complete skeletons at our disposal. In lowland bison the relative length of the thoracic limb, defined by the similarity coefficient, is greater than in lowland $\times$ Caucasian bison, due to the latter having a shorter scapula and less developed hump.

The process of decrease in the body weight of bison during different stages of phylogenesis has attracted the attention of several authors (Krysiak 1951/52; Flerov, 1979; Pucek, 1985). During the late Pleistocene these animals attained maximum body size. At that time $B$. priscus gigas, of enormous dimensions, lived in the east of Europe and Asia, in Canada and USA - the broad-headed B. latifrons, and in Alaska - B. crassicornis (Flerov, 1979). The bison of West Europe rarely equalled eastern European or Asiatic bison in size (Hiltzheimer, 1918). An interpretation of these differences is to be found in the paper by Gromova (1965), who considers that in cold climatic zones ungulate populations consisted of more strongly formed individuals than in a mild climate, and the reduction in range of isolation of small populations on islands created conditions of inbreeding leading to reduction in the body dimensions of these animals.

The lowland bison, B. bonasus bonasus, originates from the forest form of the ancient bison B. priscus (Kowalski, 1967), which inhabited the forests of Europe. The transitional forms were B. priscus mediator, of increasingly smaller size, and after it $-B$. priscus "major" (Flerov, 1979). It is possible to rule out a different genealogy for the lowland bison. It might have been a branch of the autochtonic North American taxon - B. antiquus, and the transitional form in this chain was $B$. schoetensacki (Krysiak, 1951/52; Flerov, 1979; McDonald, 1981). Hiltzheimer (1918) considers that both ways of phylogenetic development could have taken place, while Gromova (1965) supplements this by 
stating that the intermediate form between $B$. schoetensacki and the contemporary European bison was B. priscus.

McDonald (1981) is of the opinion that large forms, not only of ungulates, proper to the Pleistocene, indicate capacity for adaptation, leacing to accumulation of supplies of energy in the large body mass without the necessity for adopting a predatory way of life. This, for instance, enabled ruminants to survive unfavourable periods.

Adaptational variations may explain the reduction in body dimensions in zones with a mild climate. Reduction in the body mass of European bison as from the Holocene has been found by a large number of authors (Niezabitowski, 1927; Wróblewski, 1927; Krysiak, 1951/52; Empel, 1962; Gromova, 198̄̄; Bochenek, 1955; Ruprecht, 1976).

In relation to age it is the Pszczyna line bison which have least body weight, according to the estimate of normalized size, and this has been found in earlier studies (Empel, 1962; Roskosz et al., 1980). The fact of the presence in reproduction of the herd of the bull Pluvius II (pedigree no. 546, no. 23), the chief reproducer after Plebejer and Pless (pedigree no. 195), an animal with exceptionally small body dimensions, is suggested as the reason for this state of affairs, since it may have transmitted the dwarfing gene to future generations. Limitation of the growth of Pszczyna females was at one time connected with their excessive exploitation as brood-cows. Later studies, however, (Krasinski \& Raczyński, 1967; Raczyniski, 1978) supplied data which, together with the results of the present study, refute the hypothesis put forward as to the unfavourable effect of producing calves on the somatic development of bison cows.

It has proved possible, by using suitably prepared statistical and mathematical data, to present proof in this paper of the existence of a negative correlation between growth of European bison and degree of inbreeding.

Acknowledgements: I am greatly indebted to Professor Z. Pucek and Assistant Professor $K$. Swieżynski for their helpfulness and critical reading of the text. I should a!so like to express my thanks to Professor T. Stawinski for his valuable comments on methods and to Dr. M. Krasinska for carrying out measurements of the skulls of Caucasian bison.

\section{REFERENCES}

1. Allen J. A., 1876: The American bison, living and extinct. Memoirs Mus. Zool. Harvard Coll., 4: 1-246. Cambridge, Mass.

2. Bochenek S., 1955: Remains of the European bison, Bison bonasus (L.), from Podhale in Poland. Acta theriol., 1: 15-25. [In Polish with English \& Russian summ.].

3. Calkin V. I., 1960: Izmienčivost metapodii i jej značenie dla izučnija krupnogo rogatogo skota drevnosti. Biul. Mosk. O-va.Isp. Prirody, Biol., 70: 109-121. 
4. Calkin V. I., 1965: Seryj stepnoj skot. Biul. Mosk. O-va. Isp. Prirody, Biol., 70: 79-92.

5. Czudek A., 1930: Entwicklung und Zukunft der oberschlesischen Wisente. Polskie Tow. Leśne: 1-15. Lwów. [In Polish with German summ.].

6. Dróżđż J., 1961: A study on helminths and helminthiases in bison, Bison bonasus (L.) in Poland. Acta parasitol. polon., 9: 55-96.

7. Dróżdż J., 1967: The state of research on the helminthofauna of the European bison. Acta theriol., 12: $377-384$.

8. Duerst J. U., 1926: Vergleichende Untersuchungsmethoden am Skelett bei Säugern. Urban und Schwarzenberg: 125-530. Berlin, Wien.

9. Empel W., 1962; Morphologie des Schädels von Bison bonasus (Linnaeus, 1758). Acta theriol., 6: 53-111.

10. Empel W. \& Roskosz T., 1963: Das Skelett der Gliedmassen des Wisents, Bison bonasus (Linnaeus, 1758). Acta theriol., 7: 259-300.

11. Fisher R. A., 1936: The use of multiple measurements in taxonomic problems. Annals Eug., 7: 179-188.

12. Flerov K. K., 1932: Obzor diagnestið̌eskih priznakov belovežskogo i kavkaskogo zubrov. Biul. l'Acad. de Sc. de l'URRS. 7: 1579-1590. Moskva.

13. Flerov K. K., 1979: Sistemutika i evolucja. [In: "Zubr - morfologia, sistematika, evolucja, ekologia", ed. V. E. Sokolov]. Nauka: 9-127. Moskva.

14. Florek K., Eukaszewicz J., Perkal J., Steinhaus H., \& Zarzycki S., 1951: Sur la liaison et la division des points d'un ensemble fini. Colloq. Math., 2: 282-285. Wroclaw.

15. Frankel O. H., Saulé M. E., 1981: Conservation and evolution. Cambridge Univ. Press. Cambridge, England. [In: "Geretics and conservation: A reference for managing wild animal and plant populations", eds. C. M. Schoenenwald-Cox S. M. Chambers, B. MacBryde \& W. L. Thomas]. The Benjamin/ Cummings Publ: 1-722+XXII London, Amsterdam, Don Mills, Ontario, Tokyo.

16. Gambarjan P. P., 1972: Beg mlekopitajuscyh. Nauka: 1-334. Moskva .

17. Gill J, 1967: The physiological properties of the European Bison. Acta theriol., 12: $349-360$.

18. Grochmalicki J, 1933: Results of ten years' bison-breeding in Poland. Tow. Ochr. Zubra: 1-23. Poznan. [In Polish with English summ.].

19. Grumova V., 1965: Kratkij obzor čtvertičnyh mlekopitajušcyh Evropy. Nauka: 1-14:. Moskva.

200. Hiltzheimer M., 1918: Dritter Beitrag zur Kenntnis der Bisonten. Arch. Na= turgesch., 84: 41-87. Berlin.

21. Hutt F. B., 1964: Animal genetics. Ronald Press Co.: 1-542. New York.

22. Jaczewski Z., 1958: Reproduction of the European bison, Bison bonasus (L.), in reserves. Acta theriol., 1: 333-376. [In Polish with English \& Russian summ.].

23. Janicki S., 1938: Badania nad szkieletem żubra (Bison bonasus L.). Prace Rolniczo-Leśne P.A.U., 27: 1-55. Kraków.

24. Johansson I. \& Rendel I., 1968: Geneties and animal breeding. Oliver \& Boyd: 1-489. Edinburgh, London.

25. Juśko J,, 1953: Sexual dimorphism on bison's (Bison bonasus) skeleton. Folia morphol., 1: 1-30. Warszawa [In Polish with English summ.].

26. Kobryń H., 1973: The thorax in the European bison and other ruminants Acta theriol., 18: $314-341$. 
27. Kobryn H. \& Kobryńczuk F., 1973: Pseudoarthrosis in the European bison. Acta theriol., 18: $347-350$.

28. Kobryń H. \& Kobryńczuk F., 1976: Changes in the number and formation of lumbar vertebrae in the European bison. Acta theriol., 21: 172-173.

29. Koch W, 1927: Uber Schädelmarkmale zur Unterscheidung der rezenten Wissentrassen. Ber. Inter. Ges. Erhaltung Wisents, 2: 175-183. Berlin.

30. Koch W., 1932: Uber Wachstums- und Altersveränderungen am Skelett des Wisents. Abh. Math.- naturw. Abt. Bayer Akad. Wiss. Suppl. - Bd., 15 Abh.: 555-678. München.

31. Kowalski K, 1967: The evolution and fossil remains of the European bison. Acta theriol, 12: 335-338.

32. Krasiński Z., 1967: Free living European bison. Acta theriol., 12: 391-405.

33. Krasiński Z., 1978: Dynamics and structure of the European bison population in the Białowieza Primeval Forest. Acta theriol., 23: 3-48.

34. Krasinski Z. \& Raczyński J., 1967: The reproduction of European bison living in reserves and in freedom. Acta theriol., 12: 407-444.

35. Krysiak K., 1951/52: Two primitive aurochses (Bison priscus Bojan) skull from Polish territory. Państw. Muz. Archeol., 18: 1-199. Warszawa. [In Polish with Russian \& English summ.].

36. Krysiak K., 1967: The history of the European bison in the Biatowieza Forest and the results of its protection. Acta theriol., 12: 323-331.

37. Lasota-Moskalewska A., 1980: Morphotic changes of domestic cattle skeleton from the neolitic age to the beginning on the iron age. Wiad. Archeol., 45: 119-163. Warszawa.

38. Leithner O,, 1927: Der Ur. Ber. Inter. Gest. Erhaltung Wisents, 2: 1-140. Berlin.

39. Maciejowski J. \& Zięba J., 1982: Genetyka zwierząt i metody hodowlane. Państw. Wyd. Nauk: 1-531. Warszawa.

40. McDonald J. N., 1981: North American bison, their classification and evolution. Univ. California, Press, Berkeley: 1-316. Los Angeles, London,

41. Niezabitowski E., 1931: Szczątki kopalne zubra (Bison bonasus L.) na ziemiach Polski. Roczn. Nauk Roln. i Leśn., 26: 7-50.

42. Onopiuk W, 1984: Historia, warunki utrzymania i analiza wplywu inbredu na rozród i długość życia żubrów w Białowieży. Diss. SGGW-AR. Warszawa.

43. Pavlinin V. N., 1962: O morfologiceskoj opredelennosti populacji mlekopitajuščyh. Tr. Inst. U.F. AN. SSSR, 29: 93-119.

44. Perkal J., 1953a: O wskaźnikach antropologieznych. Przegląd antropol., 19: 209-221. Poznań.

15. Perkal J., 1953b: Taksonomia wroclawska. Przeglad antropol., 19: 82-96. Poznań.

46. Perkal J., 1958: Aralyse morphologique d'un groupe d'Équidés. Zool. pol. 8: 35-52. Poznań.

47. Pilarski W., 1956: Skeleton deformations as observed on six specimens of Bison bonasus I. Folia morphol., 7: 301-306. Warszawa. [In Polish with Russian \& English summ.].

48. Pilarski W. \& Roskosz T., 1957: Sacralization of the last lumbal vertebra in females European bison, Bison bonasus L. Folia morphol., 8: 109-119. Warszawa. [In Polish with Russian \& English summ.].

49. Poplewski R., 1948: Anatomia ssaków. Czytelnik, 2: 1-960. Stockholm. 
50. Pucek Z., 1984: What to do with the European bison, now saved from extinction? Acta zool. Fennica, 172: 187-190.

51. Pucek Z., 1985: Bison bonasus (Linnaeus, 1758) - Wisent. [In: "Handbuch der Säugetiere Europas", eds J. Niethammer and F. Krapp]. Aula Verlag, 2/II: 278-315. Wiesbaden.

52. Raczyński J., 1978: Zubr. Państw. Wyd. Roln. i Leśne: 1-272. Warszawa.

53. Rešetov V. J. \& Suhanov V. B., 1979: Postkraniatnyj skelet. [In: "Zubr morfologia, sistematika, evolucja, ekologia", d. V. E. Sokolov]. Nauka: 142-195. Moskva.

54. Roskosz T., 1962: Morphologie der Wierbelsăule des Wisents, Bison bonasus (Linnaeus, 1758). Acta theriol., 6: 113-162.

55. Roskosz T. \& Empel W., 1961: The size of the head and the height of spinous processes in the region of the withers of the European bison, Bison bonasus (Linnaeus, 1758). Acta theriol, 5: 63-71.

56. Roskosz T., Kobryńczuk F. \& Kobryń H., 1980: Speculation over European bison, Bison bonasus (Linnaeus, 1758) body weight. Ann. Wars. Agricult. SGGW-Ar. Vet. Med., 10: 1-8. Warszawa.

5i. Ruprecht A. L., 1976: Ssaki czwartorzędu białostocczyzny. Rocznik Białostocki, 13: $261-282$

58. Schmidt S., 1964: Zastosowanie metod statystycznych $w$ zootechnice. Paristw. Wyd. Roln. i Leśne, 2: 1-747. Warszawa,

59. Slatis H. M., 1960: An analysis of inbreeding in the European bison. Genetics, 45: $275-287$.

60. Srb A. M., Owen R. D. \& Edgar R. S., 1965: Genetics. W. H. Freeman \& Co.: 1-643. San Francisco, London.

61. Szarski H., 1982: Historia zwierząt kręgowych. Państw. Wyd. Nauk.: 1-522. Warszawa.

62. Sztoleman J., 1923: Le Bison d'Europe. Acta du Congres Inter. pour la Protection de la Nature: 87-92. Paris.

63. Sztolcman J., 1924: Materiaux pour l'histoire naturelle et pour l'historique du Bison d'Europe (Bison bonasus Linn,). Annls zool. Mus. Pol. Hist. Nat., 2: 49-139.

64. Scjbor J., 1960: Beobachtungen über die in Freiheit lebenden Wisente im Urwald von Bialowieza. Acta theriol., 3: 312-314.

65. Weterynaryjne Mianownictwo Anatomiczne. 1978. Państw. Wyd. Nauk.: 1-605. Warszawa.

66. Wright S., 1921: System of mating. Genetics, 6: 111-178.

67. Wróblewski K., 1927: Zubr puszczy białowieskiej. Wyd. Polskie: 1-232. Poznań.

68. Zablocki M., 1948: Neobhodimost izuðenija osobennostej zubra i ego vosstanovlenije v SSSR. Nauc.-Metod. Zapiski, 13: 128-146.

69. Zablocki M., 1956: Gosudarstvennaja kniga zubrov i bizonov. Min. Selsk. Hoz. SSSR: 1-116. Moskva.

70. Zabinski J. (Ed.), 1947-65: Pedigree book of the European bison. Paristw. Wyd. Nauk.: 1-370. Warszawa.

71. Zabińskj J. \& Raczyński J. (Eds.), 1972: European bison pedigree book 1965-69, Państw. Wyd. Nauk.: 1-78. Warszawa.

Accepted, June 19, 1985. 


\section{Franciszek KOBRYŃCZUK}

\section{WPEYW INBREDU NA KSZTAET I WIELKOSC KOSCCA ZUBRA}

\section{Streszczenie}

Przeprowadzono badania kształtu koścców żubrów, Bison bonasus bonasus (Linnaeus, 1758) w zależności od jeh przynależności do linii hodowlanej i wielkosci inbredu. Ksztalt jednostek kostnych lub ich zespolów określono metoda wskaźnikbw antropologicznych Perkala (1953a), zwanych też wskaźnikami podobiefistwa przyrodniczego. Metoda ta uwzgledniajac średnia i odchylenie standardowe szeregu liczbowego, normalizuje wybrane cechy na zero, dając obiektywny obraz podobieństwa $i$ wielkości badanych struktur. Natężenje hodowli krewniaczej wyrażono wspołczynnikami inbredu oszacowanymi na podstawie wzoru Wrighta (1921).

Materiał pochodzil od żubrów należących do trzech linii hodowlanych: psżczyniskiej, białowieskiej i nizinno-kaukaskjej. Dysponowano także 22 czaszkami żubrów kaukaskich czystej krwi, Bison bonasus caucasicus (Turkin et Satunin, 1904).

Linia pszczyńska bierze swój początek od stada czterech żubrów (1 samca i 3 samic) wywiezionych $w 1865$ roku $z$ Białowiezy do Pszczyny. Hodowla ta $w$ miedxyczasie byla jeszcze zasilona ośmioma źubrami; $w 1918$ roku rozmnożyła sie do 74 sztuk, nie licząc zwierząt sprzedanych i zastrzelonych. $Z$ pogromu stada, jaki nastapił podczas I wojny światowej, ocalała m.in. para: Plebejer (nr rod. 45) i Planta (42), która dała poczatek odrodzonej linìi pszczyńskiej. Zubry pszczynskie albo sląskie sa najbardziej zinbredowane wśród zubrów trzech wyróżionych linii. W niniejszym materiale polowę ich liczby cechuja wspolczynniki inbredu zawierajace sie $w$ granicach $0.5-0.6$.

Zubry żyjace na wolności $w$ puszezy bialowieskiej $w$ calosici uległy zagladzie w czasie I wojny światowej. Na szczęście ostatnie ich egzemplarze żyły jeszcze w niektórych ogrodach zoologicznych Europy. Obecne żubry białowieskie, nie 1iczac wyjatków, pochodza od samca Plischa (nr rod. 229) - bliskjego potomka Plebejera i Planty oraz dwóch szwedzkich samic: Biserty (93) i Biscayi (161), których rodzice - Bill (87) i Bilma (89) wywodzili się $z$ wolnej hodowli białowieskiej (Ryc. 1). Obok wysoko zinbredowanych osobników w odrodzonej linii bialowieskiej spotyka się jednostki nie pochodzące $z$ hodowli krewniaczej.

Zubry nizinno-kaukaskie, również zróżnicowane pod względem wielkości inbredu, maja geny Plebejera, Billa a także Kaukasusa (100) - przedstawiciela nieżyjących zubrow kaukaskich.

W toku badaij prześledzono wszystkie możliwe pary korelacyjne pomiędzy wskaźnikami podobieństwa przyrodniczego a współczynnikami inbredu. Dla kilkunastu istotnych zależności wyznaczono wspołłzynniki korelacji linjowej i opracowano równania regresji I-go stopnia (Tab. 5). W rownaniach tych zmiennymi zależnymi sa wskaźniki podobieństwa lub ich pochodne zaś zmiennymi niezależnymi - wspołczynniki inbredu, a niekiedy wspolczynniki pokrewienstwa do przodków lub wiek zwierząt (Tab. 6, 7, 9, 10, 11).

Oznaczenie trwalości cech nabytych wskutek hodowli wsobnej dokonano wprowadzając dodatkowe badania oparte na taksonomii i dyskryminacji. W tym celu zastosowano metodę dendrytowego porządkowania punktów (Ryc. 7, 8) oraz funkcje dyskryminacyjna Fishera.

Stwierdzono, że najbardziej podatnymi na zmianę ksztaltu pod wplywem inbredu są kości żubrów nizinno-kaukaskich a najmniej kości żubrów nizinnych. Z ko- 
lei u żubrów nizinno-kaukaskich zmiany te są najlepiej widoczne $w$ czaszce $i$ kościach kończyny piersiowej, a mniej na obszarze innych części kośćca. U żubrów tych wraz ze wzrostem inbredu dochodzi do skrócenia mózgowioczaszki i wydlużenia podstawy czaszki, w wyniku czego ma miejsce również wydlużenie i zwężenie trzewioczaszki (Tab. 6, 7, Ryc. 4, 5). Wszystkie te przeksztalcenia upodabniaja żubry njzinno-kaukaskie do żubrów kaukaskich ezystej krwi. W kostccu kończyny piersiowej żubrów nizinno-kaukaskich doszlo do skrócenia łopatki niezależnie od stopnia zinbredowania. Pociagnęlo to za soba względne wydlużenie kośćca kończyny wolnej, co jest już skorelowane dodatnio $\mathrm{z}$ wielkościa inbredu (Tab. 7). Podobne ale $\mathrm{w}$ mniejszym stopniu zaawansowane zmiany proporcji mozi na spotkać u tych żubrów w konczynie miedniczej. Pod wplywem inbredu u. żu: brów nizinno-kaukaskich gałaź żuchwy zdradza tendencję do wydłużania a klatka piersiowa do skrócenia i pogłębienia. Zmiany te sa jednak nieistotne.

Przeprowadzono analize wplywu inbredu na wielkość znormalizowana kośćcow. Stwierdzono, że kośćce żubrów wysoko zinbredowanych wszystkich linii sa mniejsze $w$ porównaniu z koścmi rówieśników o mniejszym stopniu natężenia hodowli wsobnej.

Klasyfikacja dendrytowa dowiodła, że u żubrów nizinnych czystej krwi hodowla w bliskim pokrewienstwie zaciera różnice dymorfizmu płciowego czaszki, czego nie stwierdzono u żubrów nizinno-kaukaskich.

- Porównano dane odnoszace sie do żubrów nizinnych z podobnymi dla bizonów amerykańskich. Stwierdzono, że zmienność wymiarów kośćca żubra nizinnego jest większa niż bizon $6 w$. 